\title{
Functional Roles of Long Non-coding RNAs in Motor Neuron Development and Disease
}

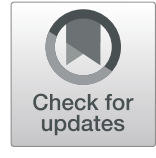

\author{
Kuan-Wei Chen ${ }^{*}$ and Jun-An Chen ${ }^{*}$ (D)
}

\begin{abstract}
Long non-coding RNAs (IncRNAs) have gained increasing attention as they exhibit highly tissue- and cell-type specific expression patterns. LncRNAs are highly expressed in the central nervous system and their roles in the brain have been studied intensively in recent years, but their roles in the spinal motor neurons (MNs) are largely unexplored. Spinal MN development is controlled by precise expression of a gene regulatory network mediated spatiotemporally by transcription factors, representing an elegant paradigm for deciphering the roles of IncRNAs during development. Moreover, many MN-related neurodegenerative diseases, such as amyotrophic lateral sclerosis (ALS) and spinal muscular atrophy (SMA), are associated with RNA metabolism, yet the link between MN-related diseases and IncRNAs remains obscure. In this review, we summarize IncRNAs known to be involved in MN development and disease, and discuss their potential future therapeutic applications.
\end{abstract}

Keywords: Long non-coding RNA, Motor neuron, Spinal muscular atrophy, Amyotrophic lateral sclerosis

\section{Introduction}

Next-generation RNA sequencing technology has revealed thousands of novel transcripts that possess no potential protein-coding elements. These RNAs are typically annotated as non-coding RNAs (ncRNAs) in the Human Genome Project and ENCODE Project [31, 59, 147]. Although most of the human genome is transcribed at certain stages during embryonic development, growth, or disease progression, ncRNAs were classically considered transcriptional noise or junk RNA due to their low expression levels relative to canonical mRNAs that generate proteins $[19,60]$. However, emerging and accumulating biochemical and genetic evidences have gradually revealed their important regulatory roles in development and disease contexts [11, 109]. In principle, regulatory ncRNAs can be further divided into two groups depending on their lengths. Small RNAs are defined as being shorter than 200 nucleotides (nt), which include well-known small RNAs such as microRNA (miRNA, 22-25 nt), Piwi interacting RNA (piRNA, 21-35 nt), small nucleolar RNA (snoRNA, 60-170 nt), and transfer RNA (tRNA, 70-100 nt). NcRNAs longer than $200 \mathrm{nt}$ are termed as long non-coding RNAs (lncRNAs) that comprise about 10 30\% of transcripts in both human (GENCODE 32) and mouse (GENCODE M23) genomes, suggesting that they

\footnotetext{
* Correspondence: kwchen@gate.sinica.edu.tw; jachen@imb.sinica.edu.tw Institute of Molecular Biology, Academia Sinica, Taipei 11529, Taiwan
}

may play largely unexplored roles in mammal physiology. LncRNAs can be classified further according to their genomic location. They can be transcribed from introns (intronic lncRNA), coding exons, $3^{\prime}$ or $5^{\prime}$ untranslated regions ( 3 ' or $5^{\prime}$ UTRs), or even in an antisense direction overlapping with their own transcripts (natural antisense transcript, NAT) $[64,130]$. In regulatory regions, upstream of promoters (promoter upstream transcript, PROMPT) [106], enhancers (eRNA) [76], intergenic regions (lincRNA) [114] and telomeres [81] can be other sources of lncRNAs. Many hallmarks of lncRNA processing are similar to those of mRNAs in post-transcription, such as nascent lncRNAs being 5'-capped, 3'-polyadenylated or alternatively spliced [19]. LncRNA production is less efficient than for mRNAs and their half-lives appear to be shorter [98]. Unlike mRNA that is directly transported to the cytoplasm for translation, many lncRNAs tend to be located in the nucleus rather than in the cytosol, as revealed by experimental approaches such as fluorescent in situ hybridization [20,67]. However, upon export to cytoplasm, some lncRNAs bind to ribosomes where they can be translated into functional peptides under specific cell contexts [20, 58]. For instance, myoregulin is encoded by a putative lncRNA and binds to sarco/endoplasmic reticulum $\mathrm{Ca}^{2+}$-ATPase (SRCA) to regulate $\mathrm{Ca}^{2+}$ import in the sarcoplasmic reticulum [6]. Nevertheless, it remains

(C) The Author(s). 2020 Open Access This article is distributed under the terms of the Creative Commons Attribution 4.0 International License (http://creativecommons.org/licenses/by/4.0/), which permits unrestricted use, distribution, and reproduction in any medium, provided you give appropriate credit to the original author(s) and the source, provide a link to the Creative Commons license, and indicate if changes were made. The Creative Commons Public Domain Dedication waiver (http://creativecommons.org/publicdomain/zero/1.0/) applies to the data made available in this article, unless otherwise stated. 
to be established if other ribosome-associated lncRNAs generate functional peptides.

\section{General function of IncRNAs}

A broad spectrum of evidence demonstrates the multifaceted roles of lncRNAs in regulating cellular processes. In the nucleus, lncRNAs participate in nearly all levels of gene regulation, from maintaining nuclear architecture to transcription per se. To establish nuclear architecture, Functional intergenic repeating RNA element (Firre) escapes from the $\mathrm{X}$ chromosome inactivation (XCI) and bridges multichromosomes, partly via association with heterogeneous nuclear ribonucleoprotein U (hnRNPU) (Figure 1a) [54]. CCCTC-binding factor (CTCF)-mediated chromosome looping can also be accomplished by lncRNAs. For example, colorectal cancer associated transcript 1 long isoform (CCAT1-L) facilitates promoter-enhancer looping at the $M Y C$ locus by interacting with CTCF, leading to stabilized $M Y C$ expression and tumorigenesis (Figure 1b) [153]. In addition, CTCF binds to many X chromosomederived lncRNAs such as $X$-inactivation intergenic transcription element (Xite), X-inactive specific transcript (Xist) and the reverse transcript of Xist (Tsix) to establish threedimensional organization of the $\mathrm{X}$ chromosome during XCI [69]. In addition to maintaining nuclear architecture, lncRNAs may also serve as building blocks of nuclear compartments. For example, nuclear enriched abundant transcript 1 (NEAT1) is the core element of paraspeckles

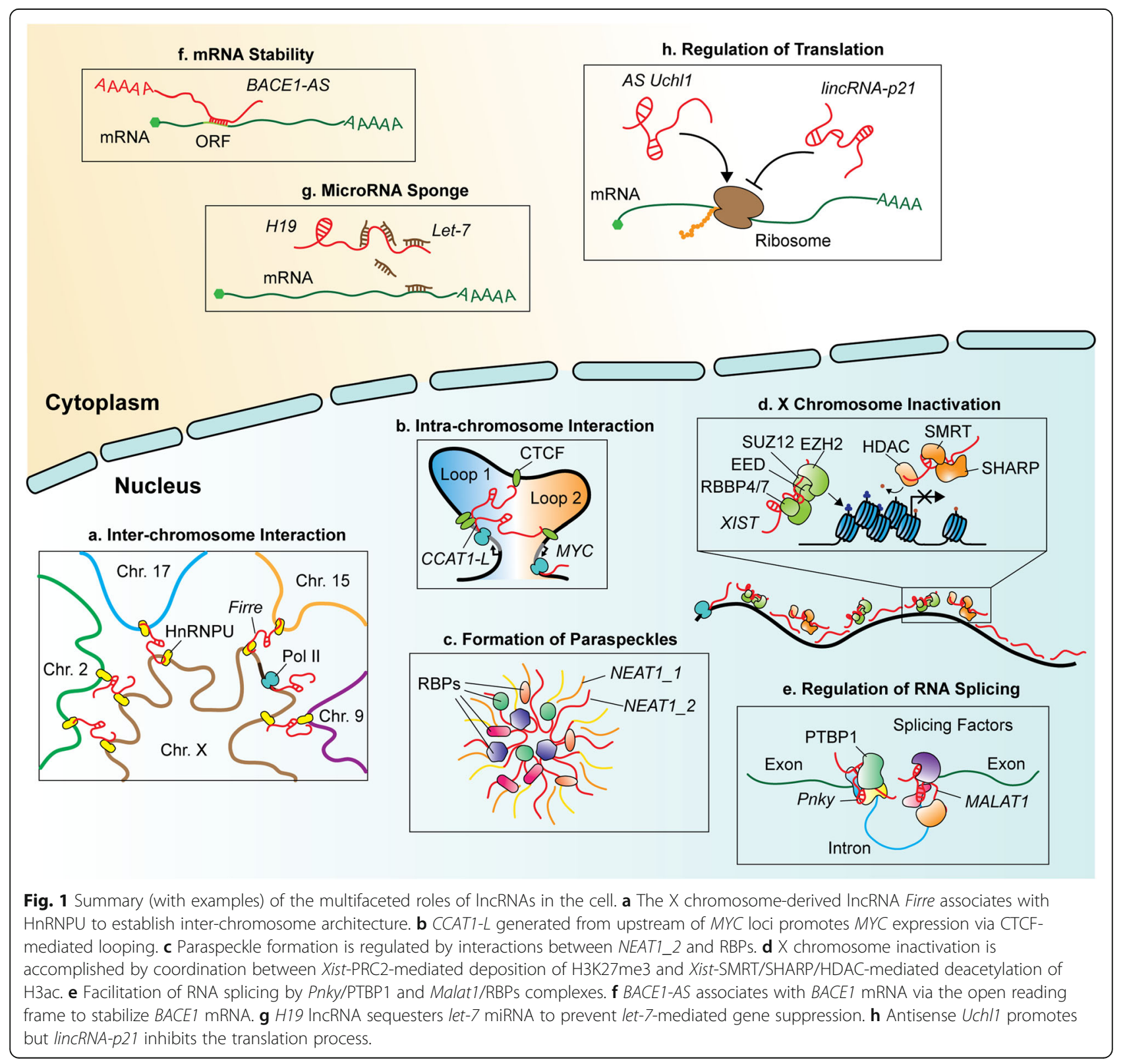


that participate in various biological processes such as nuclear retention of adenosine-to-inosine-edited mRNAs to restrict their cytoplasmic localization and viral infection response. However, the exact function of paraspeckles has yet to be fully deciphered (Figure 1c) [26, 30, 57]. LncRNAs can also function as a scaffolding component, bridging epigenetic modifiers to coordinate gene expression (e.g. activation or repression). For instance, Xist interacts with polycomb repressive complex 2 (PRC2) and the silencing mediator for retinoid and thyroid hormone receptor (SMRT)/histone deacetylase 1 (HDAC1)-associated repressor protein (SHARP) to deposit a methyl group on lysine residue 27 of histone H3 (H3K27) and to deacetylate histones, respectively, leading to transcriptional repression of the $\mathrm{X}$ chromosome (Figure 1d) [87]. Similarly, Hox antisense intergenic RNA (Hotair) bridges the PRC2 complex and lysinespecific histone demethylase 1A (LSD1, a H3K4me2 demethylase) to synergistically suppress gene expression [118, 140]. In contrast, HOXA transcript at the distal tip (HOTTIP) interacts with the tryptophan-aspartic acid repeat domain 5 - mixed-lineage leukemia 1 (WDR5-MLL1) complex to maintain the active state of the $5^{\prime}$ HOXA locus via deposition of histone 3 lysine 4 tri-methylation (H3K4me3) [149]. LncRNAs also regulate the splicing process by associating with splicing complexes. A neural-specific lncRNA, Pnky, associates with the splicing regulator polypyrimidine tract-binding protein 1 (PTBP1) to regulate splicing of a subset of neural genes [112]. Moreover, interaction between $\mathrm{Me}$ tastasis-associated lung adenocarcinoma transcript 1 (Malat1) and splicing factors such as serine/arginine rich splicing factor 1 (SRSF1) is required for alternative splicing of certain mRNAs (Figure 1e) [139].

Apart from nucleus, IncRNAs in the cytoplasm are typically involved in mRNA biogenesis. For example, in Alzheimer's disease (AD), $\beta$-secretase-1 antisense RNA (BACE1$A S)$ derived within an important $\mathrm{AD}$-associated enzyme, $B A C E 1$, elevates BACE1 protein levels by stabilizing its mRNA through a post-translational feed-forward loop [44]. Mechanistically, BACE1-AS masks the miRNA-485-5p binding site at the open reading frame of $B A C E 1 \mathrm{mRNA}$ to maintain BACE1 mRNA stability (Figure 1f) [45]. H19, a known imprinting gene expressed as a lncRNA from the maternal allele, promotes myogenesis by sequestering lethal-7 (let-7) miRNAs that, in turn, prevents let-7-mediated gene repression (Figure 1g) [62]. LncRNAs not only regulate transcription but also affect translation. Human lincRNA- $p 21$ (Trp53cor1) disrupts translation of CTNNB1 and $J U N B$ via base-pairing at multiple sites of the $5^{\prime}$ and 3 ' UTR and coding regions, resulting in recruitment of the translational repressors RCK and fragile $\mathrm{X}$ mental retardation protein (FMRP) to suppress translation (Figure 1h, right) [158]. In contrast, an antisense RNA generated from ubiquitin carboxyterminal hydrolase L1 (AS Uchl1) promotes translational expression of Uchl1 protein via its embedded short interspersed nuclear elements B2 (SINEB2). In the same study, inhibition of mammalian target of rapamycin complex 1 (mTORC1) was shown to trigger cytoplasmic localization of AS Uchl1 and to increase the association between polysomes and Uchl1 mRNA in a eukaryotic translation initiation factor 4F (eIF4F) complex independently of translation (Figure $1 \mathrm{~h}$, left) [21]. Finally, compared to mRNAs, lncRNAs seem to manifest a more tissue-specific manner [19]. In agreement with this concept, genome-wide studies have revealed that large numbers of tissue-specific lncRNAs are enriched in brain regions and some of them are involved in neurogenesis $[7,15,37$, 89]. We discuss some of these lncRNAs in greater detail below, with a particular focus on their roles during spinal MN development as this latter serves as one of the best paradigms for studying the development and degeneration of the central nervous system (CNS).

\section{Role of IncRNAs in regulating neural progenitors}

As part of the CNS, spinal MNs are located in the ventral horn of the spinal cord that conveys signals from the brainstem or sensory inputs to the terminal muscles, thereby controlling body movements. MN development requires precise spatiotemporal expression of extrinsic and intrinsic factors. Upon neurulation, the wingless/integrated protein family (WNT) and the bone morphogenetic protein family (BMP) are secreted from the roof plate of the developing neural tube to generate a dorsal to ventral gradient $[4,88]$. In contrast, sonic hedgehog (Shh) proteins emanating from the floor plate as well as the notochord generate an opposing ventral to dorsal gradient [16]. Together with paraxial mesodermexpressed retinoic acid (RA), these factors precisely pattern the neural tube into spinal cord progenitor domains $\mathrm{pd} 1 \sim 6, \mathrm{p} 0, \mathrm{p} 1, \mathrm{p} 2$, motor neuron progenitor $(\mathrm{pMN})$, and p3 along the dorso-ventral axis (Figure 2a). This patterning is mediated by distinct expression of cross-repressive transcription factors-specifically, Shh-induced class II transcription factors (Nkx2.2, Nkx2.9, Nkx6.1, Nkx6.2, Olig2) or Shh-inhibited class I transcription factors (Pax3, Pax6, Pax7, Irx3, Dbx1, Dbx2)-that further define the formation of each progenitor domain [104, 143]. All spinal MNs are generated from pMNs, and pMNs are established upon co-expression of Olig2, Nkx6.1 and Nkx6.2 under conditions of high Shh levels [2, 105, 132, 162]. Although a series of miRNAs have been shown to facilitate patterning of the neuronal progenitors in the spinal cord and controlling of MN differentiation [24, $25,27,74,141,142]$, the roles of lncRNAs during MN development are just beginning to emerge. In Table 1, we summarize the importance of IncRNAs for the regulation of transcription factors in $\mathrm{MN}$ contexts. For instance, the lncRNA lncrps25 is located near the S25 gene (which encodes a ribosomal protein) and it shares high sequence similarity with the 3' UTR of neuronal 


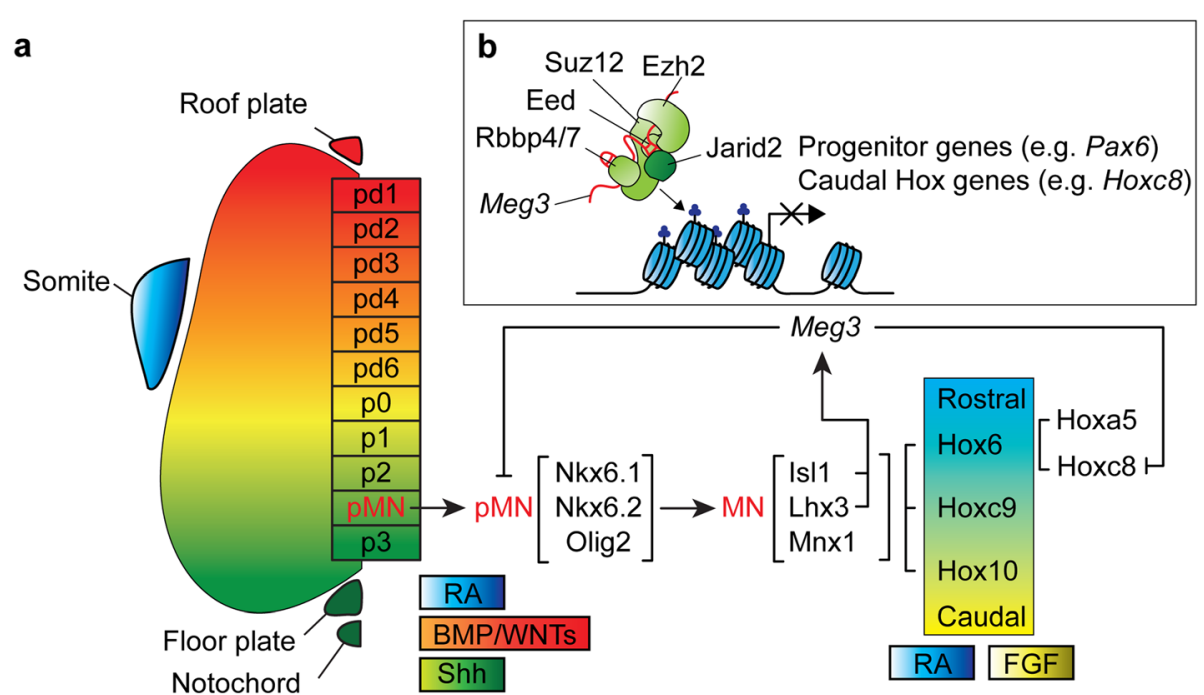

Fig. 2 Schematic illustration of spinal motor neuron development. a Notochord- and floor plate-derived sonic hedgehog protein (Shh), and roof plate-generated wingless/integrated (WNT) protein and bone morphogenetic (BMP) protein, as well as retinoic acid (RA) diffusing from the paraxial mesoderm, pattern the identities of spinal neurons by inducing cross-repressive transcription factors along the dorso-ventral axis (pd1 6 , p0, p1, p2, pMN, and p3). Motor neuron progenitors (pMNs) are generated by co-expression of Olig2, Nkx6.1 and Nkx6.2. After cell cycle exit, pMNs give rise to generic MNs by concomitantly expressing $|s| 1$, Lh×3 and Mnx1. Along the rostro-caudal axis, Hox6/Hoxc9/Hox 10 respond to RA and fibroblast growth factor (FGF) to pattern the brachial, thoracic and lumbar segments, respectively. $\mathbf{b}$ In the Hox ${ }^{\circ \text { n }}$ segment, the interaction between PRC2-Jarid2 complex and a IsI1/Lhx3 induced IncRNA Meg3 perpetuates the brachial Hoxa5 ${ }^{\circ \mathrm{n}}$ MN by repressing caudal Hoxc8 and alternative progenitor genes Irx3 and Pax6 via the maintenance of H3K27me3 epigenetic landscape in these genes. Yet the detailed mechanism how Meg3 targets to these selective genes still needs to be illustrated.

regeneration-related protein (NREP) in zebrafish. Loss of lncrps 25 reduces locomotion behavior by regulating pMN development and Olig2 expression [48]. Additionally, depletion of an MN-enriched lncRNA, i.e. Maternally expressed gene 3 (Meg3), results in upregulation of progenitor genes (i.e., Pax6 and Dbx1) in embryonic stem cell (ESC)-derived post-mitotic MNs, as well as in post-mitotic neurons in embryos. Mechanistically, Meg3 associates with the PRC2 complex to facilitate the maintenance of H3K27me3 levels in many progenitor loci, including Pax6 and Dbx1 (Figure 2b) [156]. Apart from lncRNA-mediated regulation of Pax6 in the spinal cord, corticogenesis in primates also seems to rely on the Pax6/lncRNA axis $[113,145]$. In this scenario, primatespecific lncRNA neuro-development (Lnc-ND) located in the 2p25.3 locus [131] exhibits an enriched expression pattern in neuronal progenitor cells but reduced expression in the differentiated neurons. Microdeletion of the 2p25.3 locus is associated with intellectual disability. Manipulations of $L n c-N D$ levels reveals that $L n c-N D$ is required for Pax6 expression and that overexpression of Lnc-ND by means of in utero electroporation in mouse brain promotes expansion of the Pax6-positive radial glia population [113]. Moreover, expression of the Neurogenin 1 (Ngn1) upstream enhancer-derived eRNA, $u t N g n 1$, is necessary for expression of $N g n 1$ itself in neocortical neural precursor cells and it is suppressed by PcG protein at the ESC stage [108]. Thus, IncRNAs seem to mediate a battery of transcription factors that are important for early neural progenitor patterning and this role might be conserved across vertebrates.

\section{LncRNAs in the regulation of postmitotic neurons}

In addition to their prominent functions in neural progenitors, lncRNAs also play important roles in differentiated neurons. Taking spinal MNs as an example, postmitotic MNs are generated from pMNs, and after cell cycle exit they begin to express a cohort of MNspecific markers such as Insulin gene enhancer protein 1 (Isl1), LIM/homeobox protein 3 (Lhx3), and Motor

Table 1 Proposed functions of IncRNAs during spinal motor neuron development

\begin{tabular}{llll}
\hline LncRNA & Proposed function & Organism/cell models & Reference \\
\hline Lncrps25 & Affects Olig2 expression & Zebrafish & [48] \\
CAT7/cat7l & Recruitment of PRC1 and PRC2 complexes to suppress & Zebrafish/hESC MNs & \\
& MNX1 expression in progenitor MNs & Mouse/mESC MNs & \\
Meg3 & $\begin{array}{l}\text { Association with PRC2 complex to repress MN progenitor } \\
\text { and caudal Hox genes in cervical MNs }\end{array}$ & & [156] \\
\hline
\end{tabular}


neuron and pancreas homeobox 1 (Mnx1, Hb9) (Figure 2a). Isl1/Lhx3/NLI forms an MN-hexamer complex to induce a series of $\mathrm{MN}$-specific regulators and to maintain the terminal $\mathrm{MN}$ state by repressing alternative interneuron genes $[43,72]$. Although the gene regulatory network for $\mathrm{MN}$ differentiation is very well characterized, the role of the lncRNAs involved in this process is surprisingly unclear. Only a few examples of that role have been uncovered. For instance, the lncRNA CAT7 is a polyadenylated lncRNA that lies upstream $(\sim 400 \mathrm{~kb})$ of $M N X 1$ identified from the RNA-Polycomb repressive complex 1 (PRC1) interactome. Loss of CAT7 results in de-repression of $M N X 1$ before committing to neuronal lineage through reduced PRC1 and PRC2 occupancy at the MNX1 locus in hESC MNs [115]. Furthermore, an antisense lncRNA (MNX1-AS1) shares the same promoter as MNX1, as revealed by clustered regularly interspaced short palindromic repeats (CRISPR) and CRISPR-associated protein 9 (CRISPR-Cas9) screening [53]. These results suggest that in addition to neural progenitors, lncRNAs could have another regulatory role in fine-tuning neurogenesis upon differentiation. However, whether the expression and functions of these lncRNAs are important for MN development in vivo still needs to be further validated. Future experiments to systematically identify lncRNAs involved in this process will greatly enhance our knowledge about lncRNAs and their mysterious roles in early neurogenesis.

After generic postmitotic MNs have been produced, they are further programmed into versatile subtype identities along the rostro-caudal spinal cord according to discrete expression of signaling molecules, including retinoic acid (RA), WNT, fibroblast growth factor (FGF), and growth differentiation factor 11 (GDF11), all distributed asymmetrically along the rostro-caudal axis (Figure 2a). Antagonistic signaling of rostral RA and caudal FGF/GDF11 further elicits a set of Homeobox (Hox) proteins that abut each other, namely Hox6, Hox 9 and Hox10 at the brachial, thoracic and lumbar segments, respectively [12, 77, 129]. These Hox proteins further activate downstream transcription factors that are required to establish MN subtype identity. For instance, formation of lateral motor column (LMC) MNs in the brachial and lumbar regions is regulated by Hox-activated Forkhead box protein P1 (Foxp1) [35, 119]. It is conceivable that lncRNAs might also participate in this MN subtype diversification process. For example, the lncRNA FOXP1-IT1, which is transcribed from an intron of the human FOXP1 gene, counteracts integrin Mac-1mediated downregulation of FOXP1 partly by decoying HDAC4 away from the FOXP1 promoter during macrophage differentiation [128]. However, it remains to be verified if this Foxp1/lncRNA axis is also functionally important in a spinal cord context. An array of studies in various cell models has demonstrated regulation of Hox genes by lncRNAs such as Hotair, Hottip and Haglr $[118,149,160]$. However, to date, only one study has established a link between the roles of lncRNAs in MN development and Hox regulation. Using an embryonic stem cell differentiation system, a battery of MN hallmark lncRNAs have been identified [14, 156]. Among these MN-hallmark lncRNAs, knockdown of Meg3 leads to the dysregulation of Hox genes whereby caudal Hox gene expression (Hox $9 \sim$ Hox 13 ) is increased but rostral Hox gene expression (Hox1 Hox8) declines in cervical MNs. Analysis of maternally-inherited intergenic differentially methylated region deletion $\left(I G-D M R^{\text {mat }}\right)$ mice in which Meg3 and its downstream transcripts are further depleted has further revealed ectopic expression of caudal Hoxc8 in the rostral Hoxa5 region of the brachial segment, together with a concomitant erosion of Hoxmediated downstream genes and axon arborization (Figure 2b) [156]. Given that dozens of IncRNAs have been identified as hallmarks of postmitotic MNs, it remains to be determined if these other lncRNAs are functionally important in vivo. Furthermore, lncRNA knockout has been shown to exert a very mild or no phenotype in vivo [52]. Based on several lncRNA-knockout mouse models, it seems that the physiological functions of lncRNAs might not be as prominent as transcription factors during the developmental process $[8,123]$, yet their functions become more critical under stress conditions such as cancer progression or neurodegeneration [102, 124]. Therefore, next we discuss how lncRNAs have been implicated in MN-related diseases.

\section{Motor neuron-related diseases}

Since lncRNAs regulate MN development and function, it is conceivable that their dysregulation or mutation would cause neurological disorders. Indeed, genomewide association studies (GWAS) and comparative transcriptomic studies have associated lncRNAs with a series of neurodegenerative diseases, including the age-onset $\mathrm{MN}$-associated disease amyotrophic lateral sclerosis (ALS) [86, 164]. Similarly, IncRNAs have also been linked to spinal muscular atrophy (SMA) [33, 152]. However, most of these studies have described associations but do not present unequivocal evidence of causation. Below and in Table 2, we summarize some of these studies linking lncRNAs to MN-related diseases.

\section{Amyotrophic lateral sclerosis (ALS)}

ALS is a neurodegenerative disease resulting in progressive loss of upper and lower MNs, leading to only 5-10 years median survival after diagnosis. More than $90 \%$ of ALS patients are characterized as sporadic (sALS), with less than $10 \%$ being diagnosed as familial (fALS) [17]. Some ALS-causing genes-such as superoxide dismutase 
Table 2 Proposed functions of IncRNAs in spinal motor neuron diseases

\begin{tabular}{|c|c|c|c|c|}
\hline LncRNA & Disease & Proposed function & Organism/cell models & Reference \\
\hline ATXN2-AS & ALS & $\begin{array}{l}(\mathrm{CUG})_{n} \text { repeat expansions induce } \\
\text { neurotoxicity. }\end{array}$ & $\begin{array}{l}\text { SK-N-MC neuroblastoma cells and } \\
\text { lymphoblastoid cell lines from ALS } \\
\text { patients }\end{array}$ & [75] \\
\hline $\begin{array}{l}\text { C9ORF72 antisense } \\
\text { RNA }\end{array}$ & ALS & $\begin{array}{l}\text { Forms RNA foci and repeat-associated } \\
\text { non-AUG (RAN) translation generates } \\
\text { dipeptides to cause neurotoxicity. }\end{array}$ & $\begin{array}{l}\text { Drosophila, Zebrafish/Neuro-2a, mouse } \\
\text { primary cortical and motor neurons }\end{array}$ & $\begin{array}{l}{[91,96,134,138,151,155,} \\
161]\end{array}$ \\
\hline NEAT1 & ALS & $\begin{array}{l}\text { Facilitates paraspeckle formation. } \\
\text { High levels of NEAT1 trigger } \\
\text { neurotoxicity. }\end{array}$ & Mouse/NSC-34 MN-like cells & {$[30,133]$} \\
\hline SMN-AS1 & SMA & $\begin{array}{l}\text { Recruits PRC2 complex to suppress } \\
\text { the SMN gene. }\end{array}$ & $\begin{array}{l}\text { Mouse/human SMA-iPSC-derived MNs, } \\
\text { SMN } 7 \text { mouse cortical neurons }\end{array}$ & {$[33,152]$} \\
\hline
\end{tabular}

1 (SOD1) and fused in sarcoma/translocated in sarcoma (FUS/TLS) - have been identified in both sALS and fALS patients, whereas other culprit genes are either predominantly sALS-associated (e.g. unc-13 homolog A, UNC13A) or fALS-associated (e.g. D-amino acid oxidase, DAO). These findings indicate that complex underlying mechanisms contribute to the selective susceptibility to MN degeneration in ALS. Since many characterized ALS-causing genes encode RNA-binding proteins (RBPs) - such as angiogenin (ANG), TAR DNA-binding protein 43 (TDP-43), FUS, Ataxin-2 (ATXN2), chromosome 9 open reading frame 72 (C9ORF72), TATA-box binding protein associated factor 15 (TAF15) and heterogeneous nuclear ribonucleoprotein A1 (HNRNPA1)-it is not surprising that global and/or selective RBP-RNAs, including lncRNAs, might participate in ALS onset or disease progression. Below, we discuss some representative examples.

\section{Nuclear Enriched Abundant Transcript 1 (NEAT1)}

NEAT1 is an IncRNA that appears to play an important structural role in nuclear paraspeckles [30]. Specifically, there are two NEAT1 transcripts: NEAT1_1 (3.7 kb) is dispensable whereas NEAT1_2 (23 kb) is essential for paraspeckle formation [30, 100]. However, expression of NEAT1_2 is low in the CNS of mouse ALS models relative to ALS patients, indicating a difference between rodent and human systems [101, 103]. Although crosslinking and immunoprecipitation assay (CLIP) has revealed that NEAT1 associates with TDP-43 [103, 137, 154] and FUS/TLS [103], the first evidence linking NEAT1 and paraspeckles to ALS was the observation of co-localization of NEAT1_2 with TDP-43 and FUS/TLS in paraspeckles of early-onset ALS patients [103]. A more detailed analysis has revealed that NEAT1_2 is highly enriched in neurons of the anterior horn of the spinal cord and in cortical tissues of ALS patients [126, 137]. Indeed, increased paraspeckle formation has been reported in the spinal cords of sALS and fALS patients relative to healthy individuals [126], indicating that paraspeckle formation might be a common hallmark of ALS patients. Interestingly, by utilizing an ESC-derived neuron system, a significant increase in paraspeckles was observed at the neuron progenitor stage, suggesting that paraspeckles may exist in the short time-window of neural development [126]. Manipulating ALS-related RBPs (i.e. FUS, TDP-43, and MATR3) impacts levels of $N E A T 1$, showing that these RBPs not only interact with NEAT1 but also regulate NEAT1 RNA levels. The level of NEAT1_2 increases upon FUS, TDP-43 or MATR3 deletion $[10,100]$. In contrast, elimination of TAF15, hnRNPA1 or splicing factor proline and glutamine rich (SFPQ) downregulates NEAT1_2 levels [103]. There are conflicting results with regard to whether manipulation of TDP-43 affects NEAT1_2 [100, 126]. Introducing patient-mutated FUS (e.g. P525L) also results in impaired paraspeckle formation by regulating NEAT1 transcription and misassemble of other paraspeckle proteins in the cytoplasm or nucleus $[5,127]$. Together, these results seem to indicate that mutation of ALS-related RBPs affects NEAT1 expression and paraspeckle formation during disease progression.

Although many studies have depicted how mutated ALS-related proteins regulate paraspeckle formation, levels of NEAT1_2, inappropriate protein assembly into granules or sub-organelles, and the role of NEAT1_2 in ALS progression remain poorly understood. Recently, direct activation of endogenous NEAT1 using a CRISPRCas 9 system suggested that elevated NEAT1 expression is somewhat neurotoxic in NSC-34 cells, a mouse MNlike hybrid cell line. Though no direct evidence showing that this effect is mediated by NEAT1_2 was presented in that study, it did at least exclude NEAT1_1 as the mediator [133]. This outcome may imply that increased NEAT1_2 facilitates paraspeckle formation and also somehow induces cell death or degeneration. However, more direct evidence of correlations and concordant links between RBP-lncRNA associations and ALS are needed to strengthen the rationale of utilizing lncRNAs for future therapeutic purposes. 


\section{C9ORF72 antisense RNA}

In 2011, the C9ORF72 gene with a hexanucleotide GGGGCC $\left(\mathrm{G}_{4} \mathrm{C}_{2}\right)$ repeat expansion was identified as the most frequent genetic cause of both ALS and frontotemporal dementia (FTD) in Europe and North America $[36,117]$. ALS and FTD represent a disease spectrum of overlapping genetic causes, with some patients manifesting symptoms of both diseases. Whereas ALS is defined by loss of upper and/or lower MNs leading to paralysis, FTD is characterized by degeneration of the frontal and temporal lobes and corresponding behavioral changes. The abnormal $\left(\mathrm{G}_{4} \mathrm{C}_{2}\right)$ repeat expansion in the first intron of C9ORF72 not only accounts for almost $40 \%$ of fALS and familial FTD (fFTD), but it is also found in a small cohort of sALS and sporadic FTD (sFTD) patients $[36,85,111,117]$. Healthy individuals exhibit up to 20 copies of the $\left(\mathrm{G}_{4} \mathrm{C}_{2}\right)$ repeat, but it is dramatically increased to hundreds to thousands of copies in ALS patients [36]. Loss of normal C9ORF92 protein function and gain of toxicity through abnormal repeat expansion have both been implicated in C9ORF72-associated FTD/ ALS. Several C9ORF72 transcripts have been characterized and, surprisingly, antisense transcripts were found to be transcribed from intron 1 of the C9ORF72 gene [97]. Both C9ORF72 sense (C9ORF72-S) and antisense (C9ORF72-AS) transcripts harboring hexanucleotide expansions could be translated into poly-dipeptides and were found in the MNs of C9ORF72-associated ALS patients $[47,50,95,121,151,163]$. Although C9ORF72-S RNA and consequent proteins have been investigated extensively, the functional relevance of C9ORF7-AS is still poorly understood. C9ORF72-AS contains the reverserepeated hexanucleotide (GGCCCC, $\mathrm{G}_{2} \mathrm{C}_{4}$ ) located in intron 1. Similar to C9ORF72-S, C9ORF72-AS also forms RNA foci in brain regions such as the frontal cortex and cerebellum, as well as the spinal cord (in MNs and occasionally in interneurons) of ALS $[49,163]$ and FTD patients [36, 49, 92]. Intriguingly, a higher frequency of C9ORF72-AS RNA foci and dipeptides relative to those of C9ORF72-S have been observed in the MNs of a C9ORF72-associated ALS patient, with a concomitant loss of nuclear TDP-43 [32]. In contrast, another study suggested that compared to C9ORF72-S-generated dipeptides (poly-Gly-Ala and poly-Gly-Arg), fewer dipeptides (polyPro-Arg and poly-Pro-Ala) derived from C9ORF72-AS were found in the CNS region of C9ORF72-associated FTD patients [83]. These apparently contradictory results perhaps are due to differing sensitivities of the antibodies used in those studies. It has further been suggested that a fraction of the C9ORF72-AS RNA foci is found in the perinucleolar region, indicating that nucleolar stress may contribute to C9ORF72-associated ALS/FTD disease progression [70, 93, 136]. Interestingly, compared to the C9ORF72-S $\mathrm{G}_{4} \mathrm{C}_{2}$ repeats, a large number of C9ORF72-AS
$\mathrm{G}_{2} \mathrm{C}_{4}$ repeats are associated with mono-ribosomes [135], suggesting that fewer dipeptides are generated in the former scenario. This outcome may indicate that C9ORF72-AS RNA may also contribute to the pathology caused by C9ORF72 hexanucleotide repeat expansion. Whereas C9ORF72-S can form G-quadruplexes [46, 55, $116]$ that are known to regulate transcription and gene expression [150], the C-rich C9ORF72-AS repeats may not form similar structures. Instead, the $\mathrm{G}_{2} \mathrm{C}_{4}$ expansions in C9ORF72-AS may form a C-rich motif [65] that likely affects genome stability and transcription [1]. Notably, an A-form-like double-helix with a tandem $\mathrm{C}: \mathrm{C}$ mismatch has been observed in a crystal structure of the C9ORF72$A S$ repeat expansion, suggesting that different structural forms of C9ORF72-AS might regulate disease progression [38]. Thus, during disease progression, not only may C9ORF72-AS form RNA foci to sequester RBPs, but it could also indirectly regulate gene expression via its secondary structure.

Several C9ORF72 gain-of-function and loss-of-function animal models have been generated $[9,91,138,155]$. A new Drosophila melanogaster (fly) model expressing the $\mathrm{G}_{4} \mathrm{C}_{2}$ or $\mathrm{G}_{2} \mathrm{C}_{4}$ RNA repeat followed by polyA (termed "polyA") or these repeats within spliced GFP exons followed by polyA (termed "intronic") reveals that both sense and antisense "polyA" accumulates in cytoplasm but sense and antisense "intronic" occur in the nucleus, with this latter mimicking actual pathological conditions [94]. However, expression of these repeated RNAs does not result in an obvious motor deficit phenotype, such as climbing ability of the Drosophila model, indicating that the repeats per se may not be sufficient to induce disease progression [94]. Nevertheless, applying that approach in a Danio rerio (zebrafish) model resulted in an outcome contradictory to that in Drosophila, with both sense and antisense repeated RNAs inducing clear neurotoxicity [134]. This discrepancy may be due to differing tolerances to RNA toxicity between the model species and the status of their neurons. Several mouse models have been established by introducing human C9ORF72 repeats only or the gene itself with its upstream and downstream regions via transduction of adeno-associated virus (AAV) or bacterial artificial chromosome (BAC) constructs (reviewed in [9]). In the models that harbor full-length human C9ORF72 with repeat expansions as well as upstream and downstream regions, dipeptide inclusions and RNA foci from C9ORF72-S and -AS have been observed and some of them develop motor [78] or cognition (working and spatial memory) defects [61] but others appear normal [107, 110]. Similarly, utilizing differentiated MNs from patient-derived induced pluripotent stem cells (iPSCs), C9ORF72-associated dipeptides and RNA foci have been observed but some of the expected pathologies were not fully recapitulated $[3,34,39,80]$. These inconsistent 
findings may be due to the different genetic backgrounds used or the differing stress conditions applied.

Most studies on C9ORF72 have focused on the pathology caused by repeat expansion, but how C9ORF72 itself is regulated is only beginning to be revealed. Knockdown of a transcription elongation factor, Spt4, rescues C9ORF72mediated pathology in a Drosophila model and decreases C9ORF72-S and - AS transcripts as well as poly-Gly-Pro protein production in iPSC-derived neurons from a C9ORF72associated ALS patient [66]. Another CDC73/PAF1 protein complex (PAF1C), which is a transcriptional regulator of RNA polymerase II, has been shown to positively regulate both C9ORF72-S and $-A S$ repeat transcripts [51]. Moreover, reduced expression of hnRNPA3, an $\mathrm{G}_{4} \mathrm{C}_{2}$ repeat RNA binding protein, elevates the $\mathrm{G}_{4} \mathrm{C}_{2}$ repeat RNA and dipeptide production in primary neurons [96]. Nevertheless, the RNA helicase DDX3X mitigates pathologies elicited by C9ORF72 repeat expansion by binding to $\mathrm{G}_{4} \mathrm{C}_{2}$ repeat RNA, which in turn inhibits repeat-associated non-AUG translation (RAN) but does not affect antisense $\mathrm{G}_{2} \mathrm{C}_{4}$ repeat RNA in iPSC-derived neurons and the Drosophila model [28]. Collectively, these findings reveal an alternative strategy for targeting C9ORF72 repeat expansions in that antisense oligonucleotides (ASOs) could be utilized against C9ORF72$S$ to attenuate RNA foci and reverse disease-specific transcriptional changes in iPSC-derived neurons $[39,122,161]$.

\section{Ataxin 2 antisense (ATXN2-AS) transcripts}

Ataxin-2 is an RBP and it serves as a genetic determinant or risk factor for various diseases including spinocerebellar ataxia type II (SCA2) and ALS. ATXN2-AS is transcribed from the reverse strand of intron 1 of the ATXN2 gene. Similar to the $\mathrm{G}_{4} \mathrm{C}_{2}$ repeats of C9ORF72-AS, the (CUG) expansions of ATXN2-AS may promote mRNA stability by binding to U-rich motifs in mRNAs and they have been associated with ALS risk [40, 157]. Furthermore, ATXN2$A S$ with repeat expansions were shown to induce neurotoxicity in cortical neurons in a length-dependent manner [75]. In that same study, the authors also demonstrated that it is the transcripts rather than the polypeptides generated via RAN translation that are responsible for neurotoxicity. It has been suggested that the toxicity of CUG repeats is due to hairpin formation sequestering RBPs in the cell [68]. Thus, it is likely that the RNA repeats of ATXN2-AS or C9ORF72-S/AS might function in parallel to RAN peptide-induced neurotoxicity to exacerbate degeneration of MNs in ALS.

\section{Other IncRNAs implicated in ALS}

By means of an ESC $\sim \mathrm{MN}$ system, several lncRNAs have been shown to be dysregulated in loss-of-function FUS MNs. Compared to FUS ${ }^{+/+}$MNs, Lhxlos upregulation and lncMN-1 (2610316D01Rik) and lncMN-2 (5330434G04Rik) downregulation were observed in FUS ${ }^{\mathrm{P} 17 \mathrm{~L} / \mathrm{P} 517 \mathrm{~L}}$ and $\mathrm{FUS}^{-/-}$
MNs, suggesting that loss of FUS function affects some lncRNAs conserved among mouse and human [14]. A series of lncRNAs that have not been directly implicated in ALS-associated genetic mutations have been identified to participate in ALS contexts. For instance, MALAT1 that contributes to nuclear speckles formation exhibits increased expression and TDP-43 binding in the cortical tissues of sporadic frontotemporal lobar degeneration (FTLD) patients, whereas downregulation of $\mathrm{Meg} 3$ is associated with expression and binding to TDP-43 in the same system [137]. UV-CLIP analysis has revealed that TDP-43 associates with other lncRNAs such as BDNFOS and TFEB $\alpha$ in SHSY5Y cells [154]. In muscle cells, Myolinc (AK142388) associates with TDP-43 to facilitate binding of this latter protein to myogenic genes, thereby promoting myogenesis [90]. However, whether these IncRNAs play roles in ALS progression needs to be further investigated.

Several studies using Drosophila as a model have uncovered relationships between lncRNAs and ALS. Knockdown of CR18854, an lncRNA associated with the RBP Staufen [71], rescues the climbing ability defects arising from dysregulated Cabeza (the orthologue of human FUS, hereafter referred to as dFUS) in Drosophila [99]. In contrast, knockdown of the lncRNA heat shock RNA $\omega($ hsr $\omega)$ in Drosophila MNs gives rise to severe motor deficiency by affecting presynaptic terminals. Mechanistically, $h s r \omega$ interacts with dFUS, and depletion of $h s r \omega$ results in dFUS translocation into the cytoplasm and abrogation of its nuclear function [79]. Levels of $h s r \omega$ are positively regulated by TDP-43 via direct binding of TDP-43 to the $h s r \omega$ locus in Drosophila [29]. The human orthologue of Drosophila $h s r \omega$, stress-induced Satellite III repeat RNA (Sat III), has also been shown to be elevated upon TDP-43 overexpression in the frontal cortex of FTLD-TDP patients [29]. It would be interesting to investigate the relationship between Sat III and ALS in human patients.

\section{Spinal muscular atrophy (SMA)}

Spinal muscular atrophy (SMA) is a genetic disorder characterized by prominent weakness and wasting (atrophy) of skeletal muscles due to progressive MN degeneration. SMA is the number one worldwide case of neurodegenerationassociated mortality in infants younger than two years old. SMA is caused by autosomal recessive mutation or deletion of the Survival Motor Neuron 1 (SMN1) gene, which can be ameliorated by elevated expression of $S M N 2$, a nearly identical paralogous gene of SMN1 [82]. Since the discovery of SMN1-causing phenotypes in SMA two decades ago [73], many researchers have highlighted SMN2 regulation as a rational approach to boost the generation of full-length SMN2 to offset disease effects [18, 22]. Recently, accumulating evidence has shown a critical role for lncRNAs in regulating the expression of SMN protein. For example, the 
antisense lncRNA $S M N-A S 1$ derived from the SMN locus suppresses SMN expression, and species-specific nonoverlapping SMN-antisense RNAs have been identified in mouse and human $[33,152]$. In both these studies, $S M N$ AS1 recruits the PRC2 complex to suppress expression of SMN protein, which could be rescued by either inhibiting PRC2 activity or by targeted degradation of SMN-AS1 using ASOs. Moreover, a cocktail treatment of SMN2 spliceswitching oligonucleotides (SSOs), which enhanced inclusion of exon 7 to generate functional SMN2, with $S M N$ AS1 ASOs enhanced mean survival of SMA mice from 18 days to 37 days, with $\sim 25 \%$ of the mice surviving more than 120 days [33]. These finding suggest that in addition to SSO treatment, targeting SMN-AS1 could be another potential therapeutic strategy for SMA. Moreover, transcriptome analysis has revealed certain lncRNA defects in SMA mice exhibiting early or late-symptomatic stages [13]. By comparing the translatomes (RNA-ribosome complex) of control and SMA mice, some of the lncRNAs were shown to bind to polyribosomes and to alter translation efficiency [13]. Although lncRNAs can associate with ribosomes and some of them generate functional small peptides, it needs to be established if this information is relevant in SMA contexts.

\section{LncRNAs in liquid-liquid phase separation (LLPS) and motor neuron diseases}

An emerging theme of many of the genetic mutations leading to the neurodegenerative $\mathrm{MN}$ diseases discussed above is their link to RBPs. Interestingly, many of these RBPs participate in granule formation and are associated with proteins/RNAs that undergo liquid-liquid phase separation (LLPS) (reviewed in [120]). LLPS is a phenomenon where mixtures of two or more components self-segregate into distinct liquid phases (e.g. separation of oil and water phases) and it appears to underlie formation of many transient membrane organelles, such as stress granules that contain many ribonucleoproteins (RNPs). Although it remains unclear why ubiquitously expressed RNP granule proteins aggregate in neurodegenerative disease, one study found that aggregated forms of mutant SOD1, a protein associated with fALS, accumulates in stress granules [41]. These aggregated forms induce mis-localization of several proteins associated with the miRNA biogenesis machinery, including Dicer and Drosha to stress granules. Consequently, miRNA production is compromised, with several miRNAs (i.e. $m i R-17 \sim 92$ and $m i R$-218) perhaps directly participating in ALS disease onset and progression [56, 142]. Mislocalization of ALS-related proteins such as FUS and TDP-43 in the cytosol rather than nucleus of MNs has been observed in ALS patients, but the mechanism remains unclear $[125,146]$.
A recent study highlighted differences in RNA concentration between the nucleus and cytosol. In the nucleus where the concentration of RNA is high, ALS relatedproteins such as TDP-43 and FUS are soluble, but protein aggregations form in the cytosol where the concentration of RNA is low, suggesting that RNA could serve as a buffer to prevent LLPS [84]. Collectively, these findings indicate that not only are RNAs the binding blocks for RBPs, but may also serve as a solvent to buffer RBPs and prevent LLPS. Accordingly, persistent phase separation under stress conditions could enhance formation of irreversible toxic aggregates of insoluble solidified oligomers to induce neuronal degeneration [148]. Although many neurodegenerative diseases have been associated with RNP granules, and primarily stress granules, it remains to be verified if stress granules/LLPS are causative disease factors in vivo. Many other questions remain to be answered. For instance, are the lncRNAs/RNPs mentioned above actively involved in RNP granule formation? Given that purified cellular RNA can self-assemble in vitro to form assemblies that closely recapitulate the transcriptome of stress granules and the stress granule transcriptome is dominated by lncRNAs [63, 144], it is likely that the RNA-RNA interactions mediated by abundantly expressed lncRNAs might participate in stress granule formation in ALS contexts. Similarly, do prevalent RNA modification and editing events in lncRNAs [159] change their hydrophobic or charged residues to affect LLPS and the formation of RNP granules to give rise to disease pathologies? It will be tantalizing to investigate these topics in the coming years.

\section{Conclusion and perspective}

Over the past decade, increasing evidence has challenged the central dogma of molecular biology that RNA serves solely as a temporary template between interpreting genetic information and generating functional proteins [23]. Although our understanding of lncRNAs under physiological conditions is increasing, it remains to be established if all expressed lncRNAs play particular and functional roles during embryonic development and in disease contexts. Versatile genetic strategies, including CRISPR-Cas9 technology, have allowed us to clarify the roles of IncRNA, the individual lncRNA transcripts per se, and their specific sequence elements and motifs [42]. Taking spinal MN development and degeneration as a paradigm, we have utilized ESC-derived MNs and patient iPSC-derived MNs to dissect the important roles of lncRNAs during MN development and the progression of MN-related diseases such as ALS and SMA. A systematic effort to generate MN-hallmark lncRNA knockout mice is underway, and we believe that this approach will help us understand the mechanisms underlying lncRNA activity, paving the way to develop new therapeutic strategies for treating MN-related diseases. 


\section{Abbreviations}

AD: Alzheimer's disease; ALS: Amyotrophic lateral sclerosis; ASO: Antisense oligonucleotides; ATXN2-AS: Ataxin 2 antisense transcript; BACE: $\beta$-secretase1; C9ORF72: Chromosome 9 open reading frame 72; CTCF: CCCTC-binding factor; CNS: Central nervous system; ESC: Embryonic stem cell; fALS: Familial amyotrophic lateral sclerosis; Foxp1: Forkhead box protein P1;

FTD: Frontotemporal dementia; fFTD: Familial frontotemporal dementia; FTLD: Frontotemporal lobar degeneration; FUS/TLS: Fused in sarcoma/ translocated in sarcoma; hsrw: Heat shock RNA w; Hox: Homeobox; iPSC: Induced pluripotent stem cell; LLPS: Liquid-liquid phase separation; IncRNA: Long non-coding RNA; Meg3: Maternally expressed gene 3; miRNA: microRNA; MN: Motor neuron; Mnx1: Motor neuron and pancreas homeobox 1; NEAT1: Nuclear enriched abundant transcript 1; ncRNA: Noncoding RNA; nt: Nucleotide; pMN: Motor neuron progenitor; PRC2: Polycomb repressive complex 2; RA: Retinoic acid; RBP: RNA-binding protein; RNP: Ribonucleoprotein; sALS: Sporadic amyotrophic lateral sclerosis; Shh: Sonic hedgehog; SMA: Spinal muscular atrophy; SMN: Survival motor neuron; TDP-43: TAR DNA-binding protein 43; Uchl1: Ubiquitin carboxyterminal hydrolase L1; UTR: Untranslated region; Xist: X-inactive specific transcript

\section{Acknowledgements}

We apologize to researchers not cited in the manuscript due to limited space. Special thanks to Dr. John O'Brien and Ee Shan Liau for further editing the manuscript.

\section{Authors' contributions}

K.W.C. and J.A.C. drafted, revised and approved the manuscript.

\section{Funding}

Work in the Jun-An Chen lab is supported by grants from the NHRI (NHRI-EX10810831NI), Academia Sinica (CDA-107-L05), and MOST (108-2311-B-001-011).

\section{Availability of data and materials}

Not applicable.

\section{Ethics approval and consent to participate}

Not applicable.

\section{Consent for publication}

Not applicable.

\section{Competing interests}

The authors declare that they have no competing interests.

Received: 5 December 2019 Accepted: 12 February 2020

Published online: 25 February 2020

\section{References}

1. Abou AH, Garavis M, Gonzalez C, Damha MJ. i-Motif DNA: structural features and significance to cell biology. Nucleic Acids Res. 2018;46(16):8038-56.

2. Alaynick WA, Jessell TM, Pfaff SL. SnapShot: spinal cord development. Cell. 2011;146(1):178-178 e171.

3. Almeida S, Gascon E, Tran H, Chou HJ, Gendron TF, Degroot S, Tapper AR, Sellier C, Charlet-Berguerand N, Karydas A, Seeley WW, Boxer AL, Petrucelli L, Miller BL, Gao FB. Modeling key pathological features of frontotemporal dementia with C9ORF72 repeat expansion in iPSC-derived human neurons. Acta Neuropathol. 2013;126(3):385-99.

4. Alvarez-Medina R, Cayuso J, Okubo T, Takada S, Marti E. Wnt canonical pathway restricts graded Shh/Gli patterning activity through the regulation of Gli3 expression. Development. 2008;135(2):237-47.

5. An H, Skelt L, Notaro A, Highley JR, Fox AH, La Bella V, Buchman VL, Shelkovnikova TA. ALS-linked FUS mutations confer loss and gain of function in the nucleus by promoting excessive formation of dysfunctional paraspeckles. Acta Neuropathol Commun. 2019;7(1):7.

6. Anderson DM, Anderson KM, Chang CL, Makarewich CA, Nelson BR, McAnally JR, Kasaragod P, Shelton JM, Liou J, Bassel-Duby R, Olson EN. A micropeptide encoded by a putative long noncoding RNA regulates muscle performance. Cell. 2015;160(4):595-606.

7. Aprea J, Calegari F. Long non-coding RNAs in corticogenesis: deciphering the non-coding code of the brain. EMBO J. 2015;34(23):2865-84.
8. Arnes L, Akerman I, Balderes DA, Ferrer J, Sussel L. betalinc1 encodes a long noncoding RNA that regulates islet beta-cell formation and function. Genes Dev. 2016;30(5):502-7.

9. Balendra R, Isaacs AM. C9orf72-mediated ALS and FTD: multiple pathways to disease. Nat Rev Neurol. 2018;14(9):544-58.

10. Banerjee $A$, Vest KE, Pavlath GK, Corbett $A H$. Nuclear poly(A) binding protein 1 (PABPN1) and Matrin3 interact in muscle cells and regulate RNA processing. Nucleic Acids Res. 2017;45(18):10706-25.

11. Beermann J, Piccoli MT, Viereck J, Thum T. Non-coding RNAs in Development and Disease: Background, Mechanisms, and Therapeutic Approaches. Physiol Rev. 2016;96(4):1297-325.

12. Bel-Vialar S, Itasaki N, Krumlauf R. Initiating Hox gene expression: in the early chick neural tube differential sensitivity to FGF and RA signaling subdivides the HoxB genes in two distinct groups. Development. 2002;129(22):5103-15.

13. Bernabo P, Tebaldi T, Groen EN, Lane FM, Perenthaler E, Mattedi F, Newbery HJ, Zhou H, Zuccotti P, Potrich V, Shorrock HK, Muntoni F, Quattrone A, Gillingwater TH, Viero G. In Vivo Translatome Profiling in Spinal Muscular Atrophy Reveals a Role for SMN Protein in Ribosome Biology. Cell Rep. 2017;21(4):953-65.

14. Biscarini S, Capauto D, Peruzzi G, Lu L, Colantoni A, Santini T, Shneider NA, Caffarelli E, Laneve P, Bozzoni I. Characterization of the IncRNA transcriptome in mESC-derived motor neurons: Implications for FUS-ALS. Stem Cell Res. 2018;27:172-9.

15. Briggs JA, Wolvetang EJ, Mattick JS, Rinn JL, Barry G. Mechanisms of Long Non-coding RNAs in Mammalian Nervous System Development, Plasticity, Disease, and Evolution. Neuron. 2015;88(5):861-77.

16. Briscoe J, Ericson J. The specification of neuronal identity by graded sonic hedgehog signalling. Semin Cell Dev Biol. 1999;10(3):353-62.

17. Brown RH, Al-Chalabi A. Amyotrophic Lateral Sclerosis. N Engl J Med. 2017; 377(2):162-72.

18. Burghes $A H$, Beattie CE. Spinal muscular atrophy: why do low levels of survival motor neuron protein make motor neurons sick? Nat Rev Neurosci. 2009:10(8):597-609.

19. Cabili MN, Trapnell C, Goff L, Koziol M, Tazon-Vega B, Regev A, Rinn JL. Integrative annotation of human large intergenic noncoding RNAs reveals global properties and specific subclasses. Genes Dev. 2011;25(18):1915-27.

20. Carlevaro-Fita J, Rahim A, Guigo R, Vardy LA, Johnson R. Cytoplasmic long noncoding RNAs are frequently bound to and degraded at ribosomes in human cells. RNA. 2016:22(6):867-82.

21. Carrieri C, Cimatti L, Biagioli M, Beugnet A, Zucchelli S, Fedele S, Pesce E, Ferrer I, Collavin L, Santoro C, Forrest AR, Carninci P, Biffo S, Stupka E, Gustincich S. Long non-coding antisense RNA controls Uchl1 translation through an embedded SINEB2 repeat. Nature. 2012;491(7424):454-7.

22. Chaytow H, Huang YT, Gillingwater TH, Faller KME. The role of survival motor neuron protein (SMN) in protein homeostasis. Cell Mol Life Sci. 2018; 75(21):3877-94

23. Chen JA, Conn S. Canonical mRNA is the exception, rather than the rule Genome Biol. 2017;18(1):133.

24. Chen JA, Huang YP, Mazzoni EO, Tan GC, Zavadil J, Wichterle H. Mir-17-3p controls spinal neural progenitor patterning by regulating Olig2/Irx3 crossrepressive loop. Neuron. 2011;69(4):721-35.

25. Chen JA, Wichterle $\mathrm{H}$. Apoptosis of limb innervating motor neurons and erosion of motor pool identity upon lineage specific dicer inactivation. Front Neurosci. 2012;6:69.

26. Chen $L L$, Carmichael GG. Altered nuclear retention of mRNAs containing inverted repeats in human embryonic stem cells: functional role of a nuclear noncoding RNA. Mol Cell. 2009;35(4):467-78.

27. Chen TH, Chen JA. Multifaceted roles of microRNAs: From motor neuron generation in embryos to degeneration in spinal muscular atrophy. Elife. 2019;8:e50848.

28. Cheng W, Wang S, Zhang Z, Morgens DW, Hayes LR, Lee S, Portz B, Xie Y, Nguyen BV, Haney MS, Yan S, Dong D, Coyne AN, Yang J, Xian F, Cleveland DW, Qiu Z, Rothstein JD, Shorter J, Gao FB, Bassik MC, Sun S. CRISPR-Cas9 Screens Identify the RNA Helicase DDX3X as a Repressor of C9ORF72 (GGGGCC)n RepeatAssociated Non-AUG Translation. Neuron. 2019:104(5):885-98.

29. Chung CY, Berson A, Kennerdell JR, Sartoris A, Unger T, Porta S, Kim HJ, Smith ER, Shilatifard A, Van Deerlin V, Lee VM, Chen-Plotkin A, Bonini NM. Aberrant activation of non-coding RNA targets of transcriptional elongation complexes contributes to TDP-43 toxicity. Nat Commun. 2018:9(1):4406.

30. Clemson CM, Hutchinson JN, Sara SA, Ensminger AW, Fox AH, Chess A, Lawrence JB. An architectural role for a nuclear noncoding RNA: NEAT1 RNA is essential for the structure of paraspeckles. Mol Cell. 2009;33(6):717-26. 
31. Consortium EP. An integrated encyclopedia of DNA elements in the human genome. Nature. 2012;489(7414):57-74.

32. Cooper-Knock J, Higginbottom A, Stopford MJ, Highley JR, Ince PG, Wharton SB, Pickering-Brown S, Kirby J, Hautbergue GM, Shaw PJ. Antisense RNA foci in the motor neurons of C9ORF72-ALS patients are associated with TDP-43 proteinopathy. Acta Neuropathol. 2015;130(1):63-75.

33. d'Ydewalle C, Ramos DM, Pyles NJ, Ng SY, Gorz M, Pilato CM, Ling K, Kong L, Ward AJ, Rubin LL, Rigo F, Bennett CF, Sumner CJ. The Antisense Transcript SMN-AS1 Regulates SMN Expression and Is a Novel Therapeutic Target for Spinal Muscular Atrophy. Neuron. 2017;93(1):66-79.

34. Dafinca R, Scaber J, Ababneh N, Lalic T, Weir G, Christian H, Vowles J, Douglas AG, Fletcher-Jones A, Browne C, Nakanishi M, Turner MR, WadeMartins R, Cowley SA, Talbot K. C9orf72 Hexanucleotide Expansions Are Associated with Altered Endoplasmic Reticulum Calcium Homeostasis and Stress Granule Formation in Induced Pluripotent Stem Cell-Derived Neurons from Patients with Amyotrophic Lateral Sclerosis and Frontotemporal Dementia. Stem Cells. 2016:34(8):2063-78.

35. Dasen JS, De Camilli A, Wang B, Tucker PW, Jessell TM. Hox repertoires for motor neuron diversity and connectivity gated by a single accessory factor, FoxP1. Cell. 2008;134(2):304-16.

36. DeJesus-Hernandez M, Mackenzie IR, Boeve BF, Boxer AL, Baker M, Rutherford NJ, Nicholson AM, Finch NA, Flynn H, Adamson J, Kouri N, Wojtas A, Sengdy P, Hsiung GY, Karydas A, Seeley WW, Josephs KA, Coppola G, Geschwind DH, Wszolek ZK, Feldman H, Knopman DS, Petersen RC, Miller BL, Dickson DW, Boylan KB, Graff-Radford NR, Rademakers R. Expanded GGGGCC hexanucleotide repeat in noncoding region of C9ORF72 causes chromosome 9p-linked FTD and ALS. Neuron. 2011;72(2):245-56.

37. Derrien $T$, Johnson R, Bussotti G, Tanzer A, Djebali S, Tilgner H, Guernec G, Martin D, Merkel A, Knowles DG, Lagarde J, Veeravalli L, Ruan X, Ruan Y, Lassmann T, Carninci P, Brown JB, Lipovich L, Gonzalez JM, Thomas M, Davis CA, Shiekhattar R, Gingeras TR, Hubbard TJ, Notredame C, Harrow J, Guigo R. The GENCODE v7 catalog of human long noncoding RNAs: analysis of their gene structure, evolution, and expression. Genome Res. 2012;22(9):1775-89.

38. Dodd DW, Tomchick DR, Corey DR, Gagnon KT. Pathogenic C9ORF72 Antisense Repeat RNA Forms a Double Helix with Tandem C:C Mismatches. Biochemistry. 2016;55(9):1283-6.

39. Donnelly CJ, Zhang PW, Pham JT, Haeusler AR, Mistry NA, Vidensky S, Daley EL, Poth EM, Hoover B, Fines DM, Maragakis N, Tienari PJ, Petrucelli L, Traynor BJ, Wang J, Rigo F, Bennett CF, Blackshaw S, Sattler R, Rothstein JD. RNA toxicity from the ALS/FTD C9ORF72 expansion is mitigated by antisense intervention. Neuron. 2013;80(2):415-28.

40. Elden AC, Kim HJ, Hart MP, Chen-Plotkin AS, Johnson BS, Fang X, Armakola M, Geser F, Greene R, Lu MM, Padmanabhan A, Clay-Falcone D, McCluskey L, Elman L, Juhr D, Gruber PJ, Rub U, Auburger G, Trojanowski JQ, Lee VM, Van Deerlin VM, Bonini NM, Gitler AD. Ataxin-2 intermediate-length polyglutamine expansions are associated with increased risk for ALS. Nature. 2010;466(7310):1069-75.

41. Emde A, Eitan C, Liou LL, Libby RT, Rivkin N, Magen I, Reichenstein I, Oppenheim H, Eilam R, Silvestroni A, Alajajian B, Ben-Dov IZ, Aebischer J, Savidor A, Levin Y, Sons R, Hammond SM, Ravits JM, Moller T, Hornstein E. Dysregulated miRNA biogenesis downstream of cellular stress and ALScausing mutations: a new mechanism for ALS. EMBO J. 2015;34(21):2633-51.

42. Engreitz JM, Haines JE, Perez EM, Munson G, Chen J, Kane M, McDonel PE, Guttman M, Lander ES. Local regulation of gene expression by IncRNA promoters, transcription and splicing. Nature. 2016;539(7629):452-5.

43. Erb M, Lee B, Yeon SS, Lee JW, Lee S, Lee SK. The Is|1-Lhx3 Complex Promotes Motor Neuron Specification by Activating Transcriptional Pathways that Enhance Its Own Expression and Formation. eNeuro. 2017; 4(2):ENEURO.0349-16.2017.

44. Faghihi MA, Modarresi F, Khalil AM, Wood DE, Sahagan BG, Morgan TE, Finch CE, St Laurent G 3rd, Kenny PJ, Wahlestedt C. Expression of a noncoding RNA is elevated in Alzheimer's disease and drives rapid feedforward regulation of beta-secretase. Nat Med. 2008;14(7):723-30.

45. Faghihi MA, Zhang M, Huang J, Modarresi F, Van der Brug MP, Nalls MA, Cookson MR, St-Laurent G 3rd, Wahlestedt C. Evidence for natural antisense transcript-mediated inhibition of microRNA function. Genome Biol. 2010; 11(5):R56

46. Fratta P, Mizielinska S, Nicoll AJ, Zloh M, Fisher EM, Parkinson G, Isaacs AM. C9orf72 hexanucleotide repeat associated with amyotrophic lateral sclerosis and frontotemporal dementia forms RNA G-quadruplexes. Sci Rep. 2012;2:1016.

47. Freibaum BD, Taylor JP. The Role of Dipeptide Repeats in C9ORF72-Related ALS-FTD. Front Mol Neurosci. 2017;10:35.
48. Gao T, Li J, Li N, Gao Y, Yu L, Zhuang S, Zhao Y, Dong X. Incrps25 play an essential role in motor neuron development through controlling the expression of olig2 in zebrafish. J Cell Physiol. 2020;235:3485-96.

49. Gendron TF, Bieniek KF, Zhang YJ, Jansen-West K, Ash PE, Caulfield T, Daughrity L, Dunmore JH, Castanedes-Casey M, Chew J, Cosio DM, van Blitterswijk M, Lee WC, Rademakers R, Boylan KB, Dickson DW, Petrucelli L. Antisense transcripts of the expanded C9ORF72 hexanucleotide repeat form nuclear RNA foci and undergo repeat-associated non-ATG translation in C9FTD/ALS. Acta Neuropathol. 2013;126(6):829-44.

50. Gendron TF, Chew J, Stankowski JN, Hayes LR, Zhang YJ, Prudencio M, Carlomagno Y, Daughrity LM, Jansen-West K, Perkerson EA, O'Raw A, Cook C, Pregent L, Belzil V, van Blitterswijk M, Tabassian LJ, Lee CW, Yue M, Tong J, Song Y, Castanedes-Casey M, Rousseau L, Phillips V, Dickson DW, Rademakers R, Fryer JD, Rush BK, Pedraza O, Caputo AM, Desaro P, Palmucci C, Robertson A, Heckman MG, Diehl NN, Wiggs E, Tierney M, Braun L, Farren J, Lacomis D, Ladha S, Fournier CN, McCluskey LF, Elman LB, Toledo JB, McBride JD, Tiloca C, Morelli C, Poletti B, Solca F, Prelle A, Wuu J, JockelBalsarotti J, Rigo F, Ambrose C, Datta A, Yang W, Raitcheva D, Antognetti G, McCampbell A, Van Swieten JC, Miller BL, Boxer AL, Brown RH, Bowser R, Miller TM, Trojanowski JQ, Grossman M, Berry JD, Hu WT, Ratti A, Traynor BJ, Disney MD, Benatar M, Silani V, Glass JD, Floeter MK, Rothstein JD, Boylan KB, Petrucelli L. Poly(GP) proteins are a useful pharmacodynamic marker for C9ORF72-associated amyotrophic lateral sclerosis. Sci Transl Med. 2017; 9(383):eaai7866.

51. Goodman LD, Prudencio M, Kramer NJ, Martinez-Ramirez LF, Srinivasan AR, Lan M, Parisi MJ, Zhu Y, Chew J, Cook CN, Berson A, Gitler AD, Petrucelli L, Bonini NM. Toxic expanded GGGGCC repeat transcription is mediated by the PAF1 complex in C9orf72-associated FTD. Nat Neurosci. 2019;22(6):863-74.

52. Goudarzi M, Berg K, Pieper LM, Schier AF. Individual long non-coding RNAs have no overt functions in zebrafish embryogenesis, viability and fertility. Elife. 2019;8:e40815.

53. Goyal A, Myacheva K, Gross M, Klingenberg M, Duran AB, Diederichs S. Challenges of CRISPR/Cas9 applications for long non-coding RNA genes. Nucleic Acids Res. 2017:45(3):e12.

54. Hacisuleyman E, Goff LA, Trapnell C, Williams A, Henao-Mejia J, Sun L, McClanahan P, Hendrickson DG, Sauvageau M, Kelley DR, Morse M, Engreitz J, Lander ES, Guttman M, Lodish HF, Flavell R, Raj A, Rinn JL. Topological organization of multichromosomal regions by the long intergenic noncoding RNA Firre. Nat Struct Mol Biol. 2014;21(2):198-206.

55. Haeusler AR, Donnelly CJ, Periz G, Simko EA, Shaw PG, Kim MS, Maragakis NJ, Troncoso JC, Pandey A, Sattler R, Rothstein JD, Wang J. C9orf72 nucleotide repeat structures initiate molecular cascades of disease. Nature. 2014;507(7491):195-200.

56. Hoye ML, Koval ED, Wegener AJ, Hyman TS, Yang C, O'Brien DR, Miller RL, Cole T, Schoch KM, Shen T, Kunikata T, Richard JP, Gutmann DH, Maragakis NJ, Kordasiewicz HB, Dougherty JD, Miller TM. MicroRNA Profiling Reveals Marker of Motor Neuron Disease in ALS Models. J Neurosci. 2017;37(22):5574-86.

57. Imamura K, Imamachi N, Akizuki G, Kumakura M, Kawaguchi A, Nagata K, Kato A, Kawaguchi Y, Sato H, Yoneda M, Kai C, Yada T, Suzuki Y, Yamada T, Ozawa T, Kaneki K, Inoue T, Kobayashi M, Kodama T, Wada Y, Sekimizu K, Akimitsu N. Long noncoding RNA NEAT1-dependent SFPQ relocation from promoter region to paraspeckle mediates IL8 expression upon immune stimuli. Mol Cell. 2014;53(3):393-406.

58. Ingolia NT, Lareau LF, Weissman JS. Ribosome profiling of mouse embryonic stem cells reveals the complexity and dynamics of mammalian proteomes. Cell. 2011;147(4):789-802.

59. International Human Genome Sequencing C. Finishing the euchromatic sequence of the human genome. Nature. 2004;431(7011):931-45.

60. Iyer MK, Niknafs YS, Malik R, Singhal U, Sahu A, Hosono Y, Barrette TR, Prensner JR, Evans JR, Zhao S, Poliakov A, Cao X, Dhanasekaran SM, Wu YM, Robinson DR, Beer DG, Feng FY, lyer HK, Chinnaiyan AM. The landscape of long noncoding RNAs in the human transcriptome. Nat Genet. 2015;47(3):199-208.

61. Jiang J, Zhu Q, Gendron TF, Saberi S, McAlonis-Downes M, Seelman A, Stauffer JE, Jafar-Nejad P, Drenner K, Schulte D, Chun S, Sun S, Ling SC, Myers B, Engelhardt J, Katz M, Baughn M, Platoshyn O, Marsala M, Watt A, Heyser CJ, Ard MC, De Muynck L, Daughrity LM, Swing DA, Tessarollo L, Jung CJ, Delpoux A, Utzschneider DT, Hedrick SM, de Jong PJ, Edbauer D, Van Damme P, Petrucelli L, Shaw CE, Bennett CF, Da Cruz S, Ravits J, Rigo F, Cleveland DW, Lagier-Tourenne C. Gain of Toxicity from ALS/FTD-Linked Repeat Expansions in C9ORF72 Is Alleviated by Antisense Oligonucleotides Targeting GGGGCC-Containing RNAs. Neuron. 2016;90(3):535-50. 
62. Kallen AN, Zhou XB, Xu J, Qiao C, Ma J, Yan L, Lu L, Liu C, Yi JS, Zhang H, Min W, Bennett AM, Gregory Rl, Ding Y, Huang Y. The imprinted H19 IncRNA antagonizes let-7 microRNAs. Mol Cell. 2013;52(1):101-12.

63. Khong A, Matheny T, Jain S, Mitchell SF, Wheeler JR, Parker R. The Stress Granule Transcriptome Reveals Principles of mRNA Accumulation in Stress Granules. Mol Cell. 2017:68(4):808-820 e805.

64. Khorkova O, Myers AJ, Hsiao J, Wahlestedt C. Natural antisense transcripts. Hum Mol Genet. 2014;23(R1):R54-63.

65. Kovanda A, Zalar M, Sket P, Plavec J, Rogelj B. Anti-sense DNA d(GGCCCC)n expansions in C9ORF72 form i-motifs and protonated hairpins. Sci Rep. 2015;5:17944.

66. Kramer NJ, Carlomagno Y, Zhang YJ, Almeida S, Cook CN, Gendron TF, Prudencio M, Van Blitterswijk M, Belzil V, Couthouis J, Paul JW 3rd, Goodman LD, Daughrity L, Chew J, Garrett A, Pregent L, Jansen-West K, Tabassian LJ, Rademakers R, Boylan K, Graff-Radford NR, Josephs KA, Parisi JE, Knopman DS, Petersen RC, Boeve BF, Deng N, Feng Y, Cheng TH, Dickson DW, Cohen SN, Bonini NM, Link CD, Gao FB, Petrucelli L, Gitler AD. Spt4 selectively regulates the expression of C9orf72 sense and antisense mutant transcripts. Science. 2016:353(6300):708-12

67. Kretz M, Siprashvili Z, Chu C, Webster DE, Zehnder A, Qu K, Lee CS, Flockhart RJ, Groff AF, Chow J, Johnston D, Kim GE, Spitale RC, Flynn RA, Zheng GX, Aiyer S, Raj A, Rinn JL, Chang HY, Khavari PA. Control of somatic tissue differentiation by the long non-coding RNA TINCR. Nature. 2013; 493(7431):231-5

68. Krzyzosiak WJ, Sobczak K, Wojciechowska M, Fiszer A, Mykowska A, Kozlowski P. Triplet repeat RNA structure and its role as pathogenic agent and therapeutic target. Nucleic Acids Res. 2012;40(1):11-26.

69. Kung JT, Kesner B, An JY, Ahn JY, Cifuentes-Rojas C, Colognori D, Jeon Y, Szanto A, del Rosario BC, Pinter SF, Erwin JA, Lee JT. Locus-specific targeting to the $X$ chromosome revealed by the RNA interactome of CTCF. Mol Cell. 2015;57(2):361-75.

70. Kwon I, Xiang S, Kato M, Wu L, Theodoropoulos P, Wang T, Kim J, Yun J, Xie Y, McKnight SL. Poly-dipeptides encoded by the C9orf72 repeats bind nucleoli, impede RNA biogenesis, and kill cells. Science. 2014;345(6201):1139-45.

71. Laver JD, Li X, Ancevicius K, Westwood JT, Smibert CA, Morris QD, Lipshitz HD. Genome-wide analysis of Staufen-associated mRNAs identifies secondary structures that confer target specificity. Nucleic Acids Res. 2013; 41(20):9438-60.

72. Lee S, Cuvillier JM, Lee B, Shen R, Lee JW, Lee SK. Fusion protein Is|1-Lhx3 specifies motor neuron fate by inducing motor neuron genes and concomitantly suppressing the interneuron programs. Proc Natl Acad Sci U S A. 2012;109(9):3383-8.

73. Lefebvre $S$, Burglen $L$, Reboullet $S$, Clermont $O$, Burlet $P$, Viollet $L$, Benichou $B$, Cruaud C, Millasseau P, Zeviani M, et al. Identification and characterization of a spinal muscular atrophy-determining gene. Cell. 1995;80(1):155-65.

74. Li CJ, Hong T, Tung YT, Yen YP, Hsu HC, Lu YL, Chang M, Nie Q, Chen JA. MicroRNA filters Hox temporal transcription noise to confer boundary formation in the spinal cord. Nat Commun. 2017;8:14685.

75. Li PP, Sun X, Xia G, Arbez N, Paul S, Zhu S, Peng HB, Ross CA, Koeppen AH, Margolis RL, Pulst SM, Ashizawa T, Rudnicki DD. ATXN2-AS, a gene antisense to ATXN2, is associated with spinocerebellar ataxia type 2 and amyotrophic lateral sclerosis. Ann Neurol. 2016;80(4):600-15.

76. Li W, Notani D, Rosenfeld MG. Enhancers as non-coding RNA transcription units: recent insights and future perspectives. Nat Rev Genet. 2016;17(4):207-23.

77. Liu JP, Laufer $E$, Jessell TM. Assigning the positional identity of spinal motor neurons: rostrocaudal patterning of Hox-c expression by FGFs, Gdf11, and retinoids. Neuron. 2001;32(6):997-1012.

78. Liu Y, Pattamatta A, Zu T, Reid T, Bardhi O, Borchelt DR, Yachnis AT, Ranum LP. C9orf72 BAC Mouse Model with Motor Deficits and Neurodegenerative Features of ALS/FTD. Neuron. 2016;90(3):521-34.

79. Lo PL, Yamaguchi M. RNAi of arcRNA hsromega affects sub-cellular localization of Drosophila FUS to drive neurodiseases. Exp Neurol. 2017;292:125-34.

80. Lopez-Gonzalez R, Lu Y, Gendron TF, Karydas A, Tran H, Yang D, Petrucelli L, Miller BL, Almeida S, Gao FB. Poly(GR) in C9ORF72-Related ALS/FTD Compromises Mitochondrial Function and Increases Oxidative Stress and DNA Damage in iPSC-Derived Motor Neurons. Neuron. 2016;92(2):383-91.

81. Luke B, Lingner J. TERRA: telomeric repeat-containing RNA. EMBO J. 2009; 28(17):2503-10

82. Lunn MR, Wang CH. Spinal muscular atrophy. Lancet. 2008;371(9630):2120-33.

83. Mackenzie IR, Frick P, Grasser FA, Gendron TF, Petrucelli L, Cashman NR, Edbauer D, Kremmer E, Prudlo J, Troost D, Neumann M. Quantitative analysis and clinico- pathological correlations of different dipeptide repeat protein pathologies in C9ORF72 mutation carriers. Acta Neuropathol. 2015;130(6):845-61.

84. Maharana S, Wang J, Papadopoulos DK, Richter D, Pozniakovsky A, Poser I, Bickle M, Rizk S, Guillen-Boixet J, Franzmann TM, Jahnel M, Marrone L, Chang YT, Sterneckert J, Tomancak P, Hyman AA, Alberti S. RNA buffers the phase separation behavior of prion-like RNA binding proteins. Science. 2018; 360(6391):918-21.

85. Majounie E., Renton A.E., Mok K., Dopper E.G., Waite A., Rollinson S., Chio A., Restagno G., Nicolaou N., Simon-Sanchez J., van Swieten J.C., Abramzon Y., Johnson J.O., Sendtner M., Pamphlett R., Orrell R.W., Mead S., Sidle K.C., Houlden H., Rohrer J.D., Morrison K.E., Pall H., Talbot K., Ansorge O., Chromosome A.L.S.F.T.D.C., French research network on F.F.A, Consortium I., Hernandez D.G., Arepalli S., Sabatelli M., Mora G., Corbo M., Giannini F., Calvo A., Englund E., Borghero G., Floris G.L., Remes A.M., Laaksovirta H., McCluskey L., Trojanowski J.Q., Van Deerlin V.M., Schellenberg G.D., Nalls M.A., Drory V.E., Lu C.S., Yeh T.H., Ishiura H., Takahashi Y., Tsuji S., Le Ber I., Brice A., Drepper C. , Williams N., Kirby J., Shaw P., Hardy J., Tienari P.J., Heutink P., Morris H.R., Pickering-Brown S. and Traynor B.J. Frequency of the C9orf72 hexanucleotide repeat expansion in patients with amyotrophic lateral sclerosis and frontotemporal dementia: a cross-sectional study. Lancet Neurol 11(4):323-330, 2012.

86. Maniatis S, Aijo T, Vickovic S, Braine C, Kang K, Mollbrink A, Fagegaltier D, Andrusivova Z, Saarenpaa S, Saiz-Castro G, Cuevas M, Watters A, Lundeberg J, Bonneau R, Phatnani H. Spatiotemporal dynamics of molecular pathology in amyotrophic lateral sclerosis. Science. 2019;364(6435):89-93.

87. McHugh CA, Chen CK, Chow A, Surka CF, Tran C, McDonel P, Pandya-Jones A, Blanco M, Burghard C, Moradian A, Sweredoski MJ, Shishkin AA, Su J, Lander ES, Hess S, Plath K, Guttman M. The Xist IncRNA interacts directly with SHARP to silence transcription through HDAC3. Nature. 2015;521(7551):232-6.

88. Mehler MF, Mabie PC, Zhang DM, Kessler JA. Bone morphogenetic proteins in the nervous system. Trends Neurosci. 1997;20(7):309-17.

89. Mercer TR, Dinger ME, Sunkin SM, Mehler MF, Mattick JS. Specific expression of long noncoding RNAs in the mouse brain. Proc Natl Acad Sci U S A. 2008;105(2):716-21.

90. Militello G, Hosen MR, Ponomareva Y, Gellert P, Weirick T, John D, Hindi SM, Mamchaoui K, Mouly V, Doring C, Zhang L, Nakamura M, Kumar A, Fukada SI, Dimmeler S, Uchida S. A novel long non-coding RNA Myolinc regulates myogenesis through TDP-43 and Filip1. J Mol Cell Biol. 2018;10(2):102-17.

91. Mizielinska S, Gronke S, Niccoli T, Ridler CE, Clayton EL, Devoy A, Moens T, Norona FE, Woollacott IOC, Pietrzyk J, Cleverley K, Nicoll AJ, Pickering-Brown S, Dols J, Cabecinha M, Hendrich O, Fratta P, Fisher EMC, Partridge L, Isaacs AM. C9orf72 repeat expansions cause neurodegeneration in Drosophila through arginine-rich proteins. Science. 2014;345(6201):1192-4.

92. Mizielinska S, Lashley T, Norona FE, Clayton EL, Ridler CE, Fratta P, Isaacs AM. C9orf72 frontotemporal lobar degeneration is characterised by frequent neuronal sense and antisense RNA foci. Acta Neuropathol. 2013;126(6):845-57.

93. Mizielinska S, Ridler CE, Balendra R, Thoeng A, Woodling NS, Grasser FA, Plagnol V, Lashley T, Partridge L, Isaacs AM. Bidirectional nucleolar dysfunction in C9orf72 frontotemporal lobar degeneration. Acta Neuropathol Commun. 2017;5(1):29.

94. Moens TG, Mizielinska S, Niccoli T, Mitchell JS, Thoeng A, Ridler CE, Gronke S, Esser J, Heslegrave A, Zetterberg H, Partridge L, Isaacs AM. Sense and antisense RNA are not toxic in Drosophila models of C9orf72-associated ALS/FTD. Acta Neuropathol. 2018;135(3):445-57.

95. Mori K, Arzberger T, Grasser FA, Gijselinck I, May S, Rentzsch K, Weng SM, Schludi MH, van der Zee J, Cruts M, Van Broeckhoven C, Kremmer E, Kretzschmar HA, Haass C, Edbauer D. Bidirectional transcripts of the expanded C9orf72 hexanucleotide repeat are translated into aggregating dipeptide repeat proteins. Acta Neuropathol. 2013;126(6):881-93.

96. Mori K., Nihei Y., Arzberger T., Zhou Q., Mackenzie I.R., Hermann A., Hanisch F., German Consortium for Frontotemporal Lobar D., Bavarian Brain Banking A., Kamp F., Nuscher B., Orozco D., Edbauer D. and Haass C. Reduced hnRNPA3 increases C9orf72 repeat RNA levels and dipeptide-repeat protein deposition. EMBO Rep 17(9):1314-1325, 2016.

97. Mori K, Weng SM, Arzberger T, May S, Rentzsch K, Kremmer E, Schmid B, Kretzschmar HA, Cruts M, Van Broeckhoven C, Haass C, Edbauer D. The C9orf72 GGGGCC repeat is translated into aggregating dipeptide-repeat proteins in FTLD/ALS. Science. 2013;339(6125):1335-8.

98. Mukherjee N, Calviello L, Hirsekorn A, de Pretis S, Pelizzola M, Ohler U. Integrative classification of human coding and noncoding genes through RNA metabolism profiles. Nat Struct Mol Biol. 2017;24(1):86-96. 
99. Muraoka Y, Nakamura A, Tanaka R, Suda K, Azuma Y, Kushimura Y, Lo PL, Yoshida H, Mizuta I, Tokuda T, Mizuno T, Nakagawa M, Yamaguchi M. Genetic screening of the genes interacting with Drosophila FIG 4 identified a novel link between CMT-causing gene and long noncoding RNAs. Exp Neurol. 2018;310:1-13.

100. Naganuma T, Nakagawa S, Tanigawa A, Sasaki YF, Goshima N, Hirose T. Alternative 3'-end processing of long noncoding RNA initiates construction of nuclear paraspeckles. EMBO J. 2012;31(20):4020-34.

101. Nakagawa S, Naganuma T, Shioi G, Hirose T. Paraspeckles are subpopulation-specific nuclear bodies that are not essential in mice. J Cell Biol. 2011;193(1):31-9.

102. Ng SY, Lin L, Soh BS, Stanton LW. Long noncoding RNAs in development and disease of the central nervous system. Trends Genet. 2013;29(8):461-8.

103. Nishimoto Y, Nakagawa S, Hirose T, Okano HJ, Takao M, Shibata S, Suyama S, Kuwako K, Imai T, Murayama S, Suzuki N, Okano H. The long non-coding RNA nuclear-enriched abundant transcript 1_2 induces paraspeckle formation in the motor neuron during the early phase of amyotrophic lateral sclerosis. Mol Brain. 2013;6:31.

104. Novitch BG, Chen Al, Jessell TM. Coordinate regulation of motor neuron subtype identity and pan-neuronal properties by the bHLH repressor Olig2. Neuron. 2001;31(5):773-89.

105. Novitch BG, Wichterle $H$, Jessell TM, Sockanathan S. A requirement for retinoic acid-mediated transcriptional activation in ventral neural patterning and motor neuron specification. Neuron. 2003;40(1):81-95.

106. Ntini $E$, Jarvelin Al, Bornholdt J, Chen $Y$, Boyd $M$, Jorgensen $M$, Andersson $R$, Hoof I, Schein A, Andersen PR, Andersen PK, Preker P, Valen E, Zhao X, Pelechano V, Steinmetz LM, Sandelin A, Jensen TH. Polyadenylation siteinduced decay of upstream transcripts enforces promoter directionality. Nat Struct Mol Biol. 2013;20(8):923-8.

107. O'Rourke JG, Bogdanik L, Muhammad A, Gendron TF, Kim KJ, Austin A, Cady J, Liu EY, Zarrow J, Grant S, Ho R, Bell S, Carmona S, Simpkinson M, Lall D, Wu K, Daughrity L, Dickson DW, Harms MB, Petrucelli L, Lee EB, Lutz CM, Baloh RH. C9orf72 BAC Transgenic Mice Display Typical Pathologic Features of ALS/FTD. Neuron. 2015;88(5):892-901.

108. Onoguchi M, Hirabayashi Y, Koseki H, Gotoh Y. A noncoding RNA regulates the neurogenin1 gene locus during mouse neocortical development. Proc Natl Acad Sci U S A. 2012;109(42):16939-44.

109. Perry RB, Ulitsky I. The functions of long noncoding RNAs in development and stem cells. Development. 2016;143(21):3882-94.

110. Peters OM, Cabrera GT, Tran H, Gendron TF, McKeon JE, Metterville J, Weiss A, Wightman N, Salameh J, Kim J, Sun H, Boylan KB, Dickson D, Kennedy Z, Lin Z, Zhang YJ, Daughrity L, Jung C, Gao FB, Sapp PC, Horvitz HR, Bosco DA, Brown SP, de Jong P, Petrucelli L, Mueller C, Brown RH Jr. Human C9ORF72 Hexanucleotide Expansion Reproduces RNA Foci and Dipeptide Repeat Proteins but Not Neurodegeneration in BAC Transgenic Mice. Neuron. 2015;88(5):902-9.

111. Rademakers R. C9orf72 repeat expansions in patients with ALS and FTD. Lancet Neurol. 2012;11(4):297-8.

112. Ramos AD, Andersen RE, Liu SJ, Nowakowski TJ, Hong SJ, Gertz C, Salinas RD, Zarabi H, Kriegstein AR, Lim DA. The long noncoding RNA Pnky regulates neuronal differentiation of embryonic and postnatal neural stem cells. Cell Stem Cell. 2015;16(4):439-47.

113. Rani N, Nowakowski TJ, Zhou H, Godshalk SE, Lisi V, Kriegstein AR, Kosik KS. A Primate IncRNA Mediates Notch Signaling during Neuronal Development by Sequestering miRNA. Neuron. 2016;90(6):1174-88.

114. Ransohoff JD, Wei Y, Khavari PA. The functions and unique features of long intergenic non-coding RNA. Nat Rev Mol Cell Biol. 2018;19(3):143-57.

115. Ray MK, Wiskow O, King MJ, Ismail N, Ergun A, Wang Y, Plys AJ, Davis CP, Kathrein K, Sadreyev R, Borowsky ML, Eggan K, Zon L, Galloway JL, Kingston RE. CAT7 and cat7l Long Non-coding RNAs Tune Polycomb Repressive Complex 1 Function during Human and Zebrafish Development. J Biol Chem. 2016;291(37):19558-72.

116. Reddy K, Zamiri B, Stanley SY, Macgregor RB Jr, Pearson CE. The diseaseassociated r(GGGGCC)n repeat from the C9orf72 gene forms tract lengthdependent uni- and multimolecular RNA G-quadruplex structures. J Biol Chem. 2013;288(14):9860-6.

117. Renton AE, Majounie E, Waite A, Simon-Sanchez J, Rollinson S, Gibbs JR, Schymick JC, Laaksovirta H, van Swieten JC, Myllykangas L, Kalimo H, Paetau A, Abramzon Y, Remes AM, Kaganovich A, Scholz SW, Duckworth J, Ding J, Harmer DW, Hernandez DG, Johnson JO, Mok K, Ryten M, Trabzuni D, Guerreiro RJ, Orrell RW, Neal J, Murray A, Pearson J, Jansen IE, Sondervan D,
Seelaar H, Blake D, Young K, Halliwell N, Callister JB, Toulson G, Richardson A, Gerhard A, Snowden J, Mann D, Neary D, Nalls MA, Peuralinna T, Jansson L, Isoviita VM, Kaivorinne AL, Holtta-Vuori M, Ikonen E, Sulkava R, Benatar M, Wuu J, Chio A, Restagno G, Borghero G, Sabatelli M, Consortium I, Heckerman D, Rogaeva E, Zinman L, Rothstein JD, Sendtner M, Drepper C, Eichler EE, Alkan C, Abdullaev Z, Pack SD, Dutra A, Pak E, Hardy J, Singleton A, Williams NM, Heutink P, Pickering-Brown S, Morris HR, Tienari PJ, Traynor BJ. A hexanucleotide repeat expansion in C9ORF72 is the cause of chromosome 9p21-linked ALS-FTD. Neuron. 2011;72(2):257-68.

118. Rinn JL, Kertesz M, Wang JK, Squazzo SL, Xu X, Brugmann SA, Goodnough LH, Helms JA, Farnham PJ, Segal E, Chang HY. Functional demarcation of active and silent chromatin domains in human HOX loci by noncoding RNAs. Cell. 2007;129(7):1311-23.

119. Rousso DL, Gaber ZB, Wellik D, Morrisey EE, Novitch BG. Coordinated actions of the forkhead protein Foxp1 and Hox proteins in the columnar organization of spinal motor neurons. Neuron. 2008;59(2):226-40.

120. Ryan VH, Fawzi NL. Physiological, Pathological, and Targetable Membraneless Organelles in Neurons. Trends Neurosci. 2019;42(10):693-708.

121. Saberi S, Stauffer JE, Jiang J, Garcia SD, Taylor AE, Schulte D, Ohkubo T, Schloffman CL, Maldonado M, Baughn M, Rodriguez MJ, Pizzo D, Cleveland D, Ravits J. Senseencoded poly-GR dipeptide repeat proteins correlate to neurodegeneration and uniquely co-localize with TDP-43 in dendrites of repeat-expanded C9orf72 amyotrophic lateral sclerosis. Acta Neuropathol. 2018;135(3):459-74.

122. Sareen D, O'Rourke JG, Meera P, Muhammad AK, Grant S, Simpkinson M, Bell S, Carmona S, Ornelas L, Sahabian A, Gendron T, Petrucelli L, Baughn M, Ravits J, Harms MB, Rigo F, Bennett CF, Otis TS, Svendsen CN, Baloh RH. Targeting RNA foci in iPSC-derived motor neurons from ALS patients with a C9ORF72 repeat expansion. Sci Transl Med. 2013;5(208):208ra149.

123. Sauvageau M, Goff LA, Lodato S, Bonev B, Groff AF, Gerhardinger C, Sanchez-Gomez DB, Hacisuleyman E, Li E, Spence M, Liapis SC, Mallard W, Morse M, Swerdel MR, D'Ecclessis MF, Moore JC, Lai V, Gong G, Yancopoulos GD, Frendewey D, Kellis M, Hart RP, Valenzuela DM, Arlotta P, Rinn JL. Multiple knockout mouse models reveal lincRNAs are required for life and brain development. Elife. 2013;2:e01749.

124. Schmitt AM, Chang HY. Long Noncoding RNAs in Cancer Pathways. Cancer Cell. 2016;29(4):452-63.

125. Shang Y, Huang EJ. Mechanisms of FUS mutations in familial amyotrophic lateral sclerosis. Brain Res. 2016;1647:65-78.

126. Shelkovnikova TA, Kukharsky MS, An H, Dimasi P, Alexeeva S, Shabir O, Heath PR, Buchman VL. Protective paraspeckle hyper-assembly downstream of TDP-43 loss of function in amyotrophic lateral sclerosis. Mol Neurodegener. 2018;13(1):30.

127. Shelkovnikova TA, Robinson HK, Troakes C, Ninkina N, Buchman VL. Compromised paraspeckle formation as a pathogenic factor in FUSopathies. Hum Mol Genet. 2014;23(9):2298-312.

128. Shi C, Miley J, Nottingham A, Morooka T, Prosdocimo DA, Simon DI. Leukocyte integrin signaling regulates FOXP1 gene expression via FOXP1IT1 long non-coding RNA-mediated IRAK1 pathway. Biochim Biophys Acta Gene Regul Mech. 2019;1862(4):493-508.

129. Sockanathan S, Perlmann T, Jessell TM. Retinoid receptor signaling in postmitotic motor neurons regulates rostrocaudal positional identity and axonal projection pattern. Neuron. 2003;40(1):97-111.

130. St Laurent G, Wahlestedt C, Kapranov P. The Landscape of long noncoding RNA classification. Trends Genet. 2015;31(5):239-51.

131. Stevens SJ, van Ravenswaaij-Arts CM, Janssen JW, Klein Wassink-Ruiter JS, van Essen AJ, Dijkhuizen T, van Rheenen J, Heuts-Vijgen R, Stegmann AP, Smeets EE, Engelen JJ. MYT1L is a candidate gene for intellectual disability in patients with 2p25.3 (2pter) deletions. Am J Med Genet A. 2011;155A(11):2739-45.

132. Stifani N. Motor neurons and the generation of spinal motor neuron diversity. Front Cell Neurosci. 2014;8:293.

133. Suzuki H, Shibagaki Y, Hattori S, Matsuoka M. C9-ALS/FTD-linked prolinearginine dipeptide repeat protein associates with paraspeckle components and increases paraspeckle formation. Cell Death Dis. 2019;10(10):746.

134. Swinnen B, Bento-Abreu A, Gendron TF, Boeynaems S, Bogaert E, Nuyts R, Timmers M, Scheveneels W, Hersmus N, Wang J, Mizielinska S, Isaacs AM, Petrucelli L, Lemmens R, Van Damme P, Van Den Bosch L, Robberecht W. A zebrafish model for C9orf72 ALS reveals RNA toxicity as a pathogenic mechanism. Acta Neuropathol. 2018;135(3):427-43.

135. Tabet R, Schaeffer L, Freyermuth F, Jambeau M, Workman M, Lee CZ, Lin CC, Jiang J, Jansen-West K, Abou-Hamdan H, Desaubry L, Gendron T, Petrucelli L, Martin F, Lagier-Tourenne C. CUG initiation and frameshifting 
enable production of dipeptide repeat proteins from ALS/FTD C9ORF72 transcripts. Nat Commun. 2018;9(1):152.

136. Tao Z, Wang H, Xia Q, Li K, Li K, Jiang X, Xu G, Wang G, Ying Z. Nucleolar stress and impaired stress granule formation contribute to C9orf72 RAN translation-induced cytotoxicity. Hum Mol Genet. 2015;24(9):2426-41.

137. Tollervey JR, Curk T, Rogelj B, Briese M, Cereda M, Kayikci M, Konig J, Hortobagyi T, Nishimura AL, Zupunski V, Patani R, Chandran S, Rot G, Zupan B, Shaw CE, Ule J. Characterizing the RNA targets and position-dependent splicing regulation by TDP-43. Nat Neurosci. 2011;14(4):452-8.

138. Tran H, Almeida S, Moore J, Gendron TF, Chalasani U, Lu Y, Du X, Nickerson JA, Petrucelli L, Weng Z, Gao FB. Differential Toxicity of Nuclear RNA Foci versus Dipeptide Repeat Proteins in a Drosophila Model of C9ORF72 FTD/ ALS. Neuron. 2015;87(6):1207-14.

139. Tripathi V, Ellis JD, Shen Z, Song DY, Pan Q, Watt AT, Freier SM, Bennett CF, Sharma A, Bubulya PA, Blencowe BJ, Prasanth SG, Prasanth KV. The nuclearretained noncoding RNA MALAT1 regulates alternative splicing by modulating SR splicing factor phosphorylation. Mol Cell. 2010;39(6):925-38.

140. Tsai MC, Manor O, Wan Y, Mosammaparast N, Wang JK, Lan F, Shi Y, Segal E, Chang HY. Long noncoding RNA as modular scaffold of histone modification complexes. Science. 2010;329(5992):689-93.

141. Tung YT, Lu YL, Peng KC, Yen YP, Chang M, Li J, Jung H, Thams S, Huang YP, Hung JH, Chen JA. Mir-17 approximately 92 Governs Motor Neuron Subtype Survival by Mediating Nuclear PTEN. Cell Rep, 2015.

142. Tung YT, Peng KC, Chen YC, Yen YP, Chang M, Thams S, Chen JA. Mir-17 approximately 92 Confers Motor Neuron Subtype Differential Resistance to ALS-Associated Degeneration. Cell Stem Cell. 2019;25(2):193-209.

143. Vallstedt A, Muhr J, Pattyn A, Pierani A, Mendelsohn M, Sander M, Jessell TM, Ericson J. Different levels of repressor activity assign redundant and specific roles to $\mathrm{Nk \times 6}$ genes in motor neuron and interneuron specification. Neuron. 2001;31(5):743-55.

144. Van Treeck B, Protter DSW, Matheny T, Khong A, Link CD, Parker R. RNA selfassembly contributes to stress granule formation and defining the stress granule transcriptome. Proc Natl Acad Sci U S A. 2018;115(11):2734-9.

145. Vance KW, Sansom SN, Lee S, Chalei V, Kong L, Cooper SE, Oliver PL, Ponting CP. The long non-coding RNA Paupar regulates the expression of both local and distal genes. EMBO J. 2014;33(4):296-311.

146. Vanden BL, Callaerts P, Dermaut B. TDP-43-mediated neurodegeneration: towards a loss-of-function hypothesis? Trends Mol Med. 2014;20(2):66-71.

147. Venter JC, Adams MD, Myers EW, Li PW, Mural RJ, Sutton GG, Smith HO, Yandell M, Evans CA, Holt RA, Gocayne JD, Amanatides P, Ballew RM, Huson DH, Wortman JR, Zhang Q, Kodira CD, Zheng XH, Chen L, Skupski M, Subramanian G, Thomas PD, Zhang J, Gabor Miklos GL, Nelson C, Broder S, Clark AG, Nadeau J, McKusick VA, Zinder N, Levine AJ, Roberts RJ, Simon M, Slayman C, Hunkapiller M, Bolanos R, Delcher A, Dew I, Fasulo D, Flanigan M, Florea L, Halpern A, Hannenhalli S, Kravitz S, Levy S, Mobarry C, Reinert K, Remington K, Abu-Threideh J, Beasley E, Biddick K, Bonazzi V, Brandon R, Cargill M, Chandramouliswaran I, Charlab R, Chaturvedi K, Deng Z, Di Francesco V, Dunn P, Eilbeck K, Evangelista C, Gabrielian AE, Gan W, Ge W, Gong F, Gu Z, Guan P, Heiman TJ, Higgins ME, Ji RR, Ke Z, Ketchum KA, Lai Z, Lei Y, Li Z, Li J, Liang Y, Lin X, Lu F, Merkulov GV, Milshina N, Moore HM, Naik AK, Narayan VA, Neelam B, Nusskern D, Rusch DB, Salzberg S, Shao W, Shue B, Sun J, Wang Z, Wang A, Wang X, Wang J, Wei M, Wides R, Xiao C, Yan C, Yao A, Ye J, Zhan M, Zhang W, Zhang H, Zhao Q, Zheng L, Zhong F, Zhong W, Zhu S, Zhao S, Gilbert D, Baumhueter S, Spier G, Carter C, Cravchik A, Woodage T, Ali F, An H, Awe A, Baldwin D, Baden H, Barnstead M, Barrow I, Beeson K, Busam D, Carver A, Center A, Cheng ML, Curry L, Danaher S, Davenport L, Desilets R, Dietz S, Dodson K, Doup L, Ferriera S, Garg N, Gluecksmann A, Hart B, Haynes J, Haynes C, Heiner C, Hladun S, Hostin D, Houck J, Howland T, Ibegwam C, Johnson J, Kalush F, Kline L, Koduru S, Love A, Mann F, May D, McCawley S, Mclntosh T, McMullen I, Moy M, Moy L, Murphy B, Nelson K, Pfannkoch C, Pratts E, Puri V, Qureshi H, Reardon M, Rodriguez R, Rogers YH, Romblad D, Ruhfel B, Scott R, Sitter C, Smallwood M, Stewart E, Strong R, Suh E, Thomas R, Tint NN, Tse S, Vech C, Wang G, Wetter J, Williams S, Williams M, Windsor S, Winn-Deen E, Wolfe K, Zaveri J, Zaveri K, Abril JF, Guigo R, Campbell MJ, Sjolander KV, Karlak B, Kejariwal A, Mi H, Lazareva B, Hatton T, Narechania A, Diemer K, Muruganujan A, Guo N, Sato S, Bafna V, Istrail S, Lippert R, Schwartz R, Walenz B, Yooseph S, Allen D, Basu A, Baxendale J, Blick L, Caminha M, Carnes-Stine J, Caulk P, Chiang YH, Coyne M, Dahlke C, Mays A, Dombroski M, Donnelly M, Ely D, Esparham S, Fosler C, Gire H, Glanowski S, Glasser K, Glodek A, Gorokhov M, Graham K, Gropman B, Harris M, Heil J, Henderson S,
Hoover J, Jennings D, Jordan C, Jordan J, Kasha J, Kagan L, Kraft C, Levitsky A, Lewis M, Liu X, Lopez J, Ma D, Majoros W, McDaniel J, Murphy S, Newman M, Nguyen T, Nguyen N, Nodell M, Pan S, Peck J, Peterson M, Rowe W, Sanders R, Scott J, Simpson M, Smith T, Sprague A, Stockwell T, Turner R, Venter E, Wang M, Wen M, Wu D, Wu M, Xia A, Zandieh A, Zhu X. The sequence of the human genome. Science. 2001;291(5507):1304-51.

148. Vogler TO, Wheeler JR, Nguyen ED, Hughes MP, Britson KA, Lester E, Rao B, Betta ND, Whitney ON, Ewachiw TE, Gomes E, Shorter J, Lloyd TE, Eisenberg DS, Taylor JP, Johnson AM, Olwin BB, Parker R. TDP-43 and RNA form amyloidlike myo-granules in regenerating muscle. Nature. 2018;563(7732):508-13.

149. Wang KC, Yang YW, Liu B, Sanyal A, Corces-Zimmerman R, Chen Y, Lajoie BR, Protacio A, Flynn RA, Gupta RA, Wysocka J, Lei M, Dekker J, Helms JA, Chang HY. A long noncoding RNA maintains active chromatin to coordinate homeotic gene expression. Nature. 2011;472(7341):120-4.

150. Wang X, Goodrich KJ, Conlon EG, Gao J, Erbse AH, Manley JL, Cech TR. C9orf72 and triplet repeat disorder RNAs: G-quadruplex formation, binding to PRC2 and implications for disease mechanisms. RNA. 2019;25(8):935-47.

151. Wen X, Tan W, Westergard T, Krishnamurthy K, Markandaiah SS, Shi Y, Lin S, Shneider NA, Monaghan J, Pandey UB, Pasinelli P, Ichida JK, Trotti D. Antisense proline-arginine RAN dipeptides linked to C9ORF72-ALS/FTD form toxic nuclear aggregates that initiate in vitro and in vivo neuronal death. Neuron. 2014;84(6):1213-25.

152. Woo CJ, Maier VK, Davey R, Brennan J, Li G, Brothers J 2nd, Schwartz B, Gordo S, Kasper A, Okamoto TR, Johansson HE, Mandefro B, Sareen D, Bialek P, Chau BN, Bhat B, Bullough D, Barsoum J. Gene activation of SMN by selective disruption of IncRNA-mediated recruitment of PRC2 for the treatment of spinal muscular atrophy. Proc Natl Acad Sci U S A. 2017;114(8):E1509-18.

153. Xiang JF, Yin QF, Chen T, Zhang Y, Zhang XO, Wu Z, Zhang S, Wang HB, Ge J, Lu X, Yang L, Chen LL. Human colorectal cancer-specific CCAT1-L IncRNA regulates longrange chromatin interactions at the MYC locus. Cell Res. 2014;24(5):513-31.

154. Xiao S, Sanelli T, Dib S, Sheps D, Findlater J, Bilbao J, Keith J, Zinman L, Rogaeva E, Robertson J. RNA targets of TDP-43 identified by UV-CLIP are deregulated in ALS. Mol Cell Neurosci. 2011;47(3):167-80.

155. Xu Z, Poidevin M, Li X, Li Y, Shu L, Nelson DL, Li H, Hales CM, Gearing M, Wingo TS, Jin P. Expanded GGGGCC repeat RNA associated with amyotrophic lateral sclerosis and frontotemporal dementia causes neurodegeneration. Proc Natl Acad Sci U S A. 2013;110(19):7778-83.

156. Yen YP, Hsieh WF, Tsai YY, Lu YL, Liau ES, Hsu HC, Chen YC, Liu TC, Chang M, Li J, Lin SP, Hung JH, Chen JA. DIk1-Dio3 locus-derived IncRNAs perpetuate postmitotic motor neuron cell fate and subtype identity. Elife. 2018;7:e38080.

157. Yokoshi M, Li Q, Yamamoto M, Okada H, Suzuki Y, Kawahara Y. Direct binding of Ataxin-2 to distinct elements in 3' UTRs promotes mRNA stability and protein expression. Mol Cell. 2014;55(2):186-98.

158. Yoon JH, Abdelmohsen $\mathrm{K}$, Srikantan S, Yang X, Martindale JL, De S, Huarte M, Zhan M, Becker KG, Gorospe M. LincRNA-p21 suppresses target mRNA translation. Mol Cell. 2012;47(4):648-55.

159. Zaccara S, Ries RJ, Jaffrey SR. Reading, writing and erasing mRNA methylation. Nat Rev Mol Cell Biol. 2019;20(10):608-24.

160. Zakany J, Darbellay F, Mascrez B, Necsulea A, Duboule D. Control of growth and gut maturation by HoxD genes and the associated IncRNA Haglr. Proc Natl Acad Sci U S A. 2017:114(44):E9290-9.

161. Zhang K, Donnelly CJ, Haeusler AR, Grima JC, Machamer JB, Steinwald P, Daley EL, Miller SJ, Cunningham KM, Vidensky S, Gupta S, Thomas MA, Hong I, Chiu SL, Huganir RL, Ostrow LW, Matunis MJ, Wang J, Sattler R, Lloyd TE, Rothstein JD. The C9orf72 repeat expansion disrupts nucleocytoplasmic transport. Nature. 2015;525(7567):56-61.

162. Zhou Q, Anderson DJ. The bHLH transcription factors OLIG2 and OLIG1 couple neuronal and glial subtype specification. Cell. 2002;109(1):61-73.

163. Zu T, Liu Y, Banez-Coronel M, Reid T, Pletnikova O, Lewis J, Miller TM, Harms MB, Falchook AE, Subramony SH, Ostrow LW, Rothstein JD, Troncoso JC, Ranum LP. RAN proteins and RNA foci from antisense transcripts in C9ORF72 ALS and frontotemporal dementia. Proc Natl Acad Sci U S A. 2013;110(51):E4968-77.

164. Zucca S, Gagliardi S, Pandini C, Diamanti L, Bordoni M, Sproviero D, Arigoni M, Olivero M, Pansarasa O, Ceroni M, Calogero R, Cereda C. RNA-Seq profiling in peripheral blood mononuclear cells of amyotrophic lateral sclerosis patients and controls. Sci Data. 2019;6:190006.

\section{Publisher's Note}

Springer Nature remains neutral with regard to jurisdictional claims in published maps and institutional affiliations. 